\title{
ROLE OF HEREDITY, ENDOGENOUS AND EXOGENOUS FACTORS IN GASTRIC CANCER
}

Ershov PV $\bowtie$, Veselovsky EM, Konstantinova YuS

Centre for Strategic Planning and Management of Biomedical Health Risks of FMBA, Moscow, Russia

Gastric cancer (GC) usually has an unfavorable prognosis: the five-year survival rate is $20-30 \%$ in most world regions. Timely diagnosis and prevention of risk factors may reduce mortality from GC. This review discusses the meta-analyses of 40 endogenous and exogenous factors associated with GC. GC is significantly associated with family history; dietary preferences (increased consumption of roast and smoked red meat, hot foods, pickles, salt (over 5-6 g/day), nitrates (over 20 mg/L drinking water); lifestyle (smoking, opium use, strong alcohol, beer, stress); some diseases including gastroesophageal reflux disease, diabetes mellitus, obesity, and autoimmune disorders; infections (Helicobacter pylori, human papillomavirus, Epstein-Barr virus); ionizing radiation, and professional hazards. Data suggesting associations between the risk of GC and the consumption of coffee, tea, high-fat foods, simple carbohydrates, folic acid, sleep duration, and blood cholesterol turned out to be conflicting due to the inconsistencies of the results between cohort and case-control studies. About $3 \%$ of all gastric cancers are linked to hereditary syndromes associated with pathogenic variants of CDH1, STK11, SMAD4, BMPR1A, TP53, MYH, APC, PTEN, ATM, BRCA1, and some other genes. Keywords: gastric cancer, risk factors, polymorphism, hereditary syndrome, occupational hazards

Author contribution: Ershov PV performed literature search and wrote the draft of the manuscript; Veselovsky EM performed literature search, wrote the Genetic factors for GC risk section and edited the manuscript; Konstantinova YuS performed literature search, proposed the concept of the study and edited the manuscript.

$\square$ Correspondence should be addressed: Pavel V. Ershov

Pogodinskaya, 10, str. 1, Moscow, 119121; pavel79@inbox.ru

Received: 26.10.2020 Accepted: 25.11.2020 Published online: 18.12.2020

DOI: $10.47183 /$ mes.2020.023

\section{ВКЛАД НАСЛЕДСТВЕННОСТИ И СОВОКУПНОСТИ ЭНДОГЕННЫХ И ЭКЗОГЕННЫХ ФАКТОРОВ РИСКА В РАЗВИТИЕ РАКА ЖЕЛУДКА}

П. В. Ершов

Центр стратегического планирования и управления медико-биологическими рисками здоровью Федерального медико-биологического агентства, Москва, Россия Прогноз рака желудка (РЖ) обычно неблагоприятен: пятилетняя выживаемость в большинстве регионов составляет 20-30\%. Выявление злокачественного новообразования на ранних стадиях, так же как и своевременное исключение факторов риска, помогут снизить смертность от РЖ. В обзоре обсуждаются данные публикаций по мета-анализу 40 эндогенных и экзогенных факторов, связанных с РЖ. Статистически значимый риск РЖ был ассоциирован с семейным анамнезом; некоторыми диетическими особенностями (высокое потребление жареного и копченого красного мяса, горячей пищи, маринованных продуктов, поваренной соли (свыше 5-6 г/сут.), нитратов (свыше 20 мг/л питьевой воды); стилем жизни (табакокурение, потребление опиума, крепкого алкоголя и пива, стресс); такими заболеваниями, как гастроэзофагеальная рефлюксная болезнь, сахарный диабет, ожирение, аутоиммунные нарушения; инфекциями (Helicobacter pylori, вирус папиломы человека, вирус Эпштейна-Барр); ионизирующим излучением; профессиональными вредностями. Данные о связи риска РЖ с потреблением кофе, чая, пищи с высоким содержанием жиров и быстроусваиваемых углеводов, фолиевой кислоты, продолжительностью сна, содержанием холестерина крови оказались противоречивыми, вследствие отсутствия согласованности результатов когортных исследований и «случай-контроль». Около 3\% всех случаев РЖ обусловлены наследственными синдромами, ассоциированными с патогенными вариантами генов CDH1, STK11, SMAD4, BMPR1A, TP53, MYH, APC, PTEN, ATM, BRCA1 и др.

Ключевые слова: рак желудка, фактор риска, генетический полиморфизм, наследственный синдром, профессиональная вредность

Вклад авторов: П. В. Ершов - поиск литературы, написание текста статьи, Е. М. Веселовский - поиск литературы, написание главы «Генетические факторы риска РЖ», редактирование статьи, Ю. С. Константинова - поиск литературы, концептуализация и редактирование статьи.

$\triangle$ Для корреспонденции: Павел Викторович Ершов

ул. Погодинская, д. 10, стр. 1, г. Москва, 119121; pavel79@inbox.ru

Статья получена: 26.10.2020 Статья принята к печати: 25.11.2020 Опубликована онлайн: 18.12.2020

DOI: $10.47183 /$ mes.2020.023

Gastric cancer (GC) is usually diagnosed in advanced stages. The neoplastic transformation of gastric mucosa has a complex nature shaped by the interplay of endogenous and exogenous factors, from genetic polymorphisms to lifestyle choices and occupational hazards. Early detection and elimination of modifiable high-risk factors reinforced by the promotion of behaviors that can lower the risk of GC is the mainstay of cancer prevention strategies. The leading high-risk factors for GC are male sex (men are twice as likely to develop GC than women), Helicobacter pylori (H. pylori) infection, family history of cancer and smoking.

Across continents, the highest incidence of GC is observed in East Asia, followed by Central and Eastern Europe, South America, Southern Europe, Northern Europe, Central Asia, North America, and Africa [1]. Within countries, differences in GC incidence are linked to the ethnic composition of the resident population, culture, climate, and regional geochemistry. Survival depends on the stage of the disease at diagnosis, its classification category and molecular subtype. GC usually has a poor prognosis: the 5 -year survival rate varies from $20 \%$ to $30 \%$ in most world regions [2], except Japan, where it exceeds $70 \%$ for stages I and II [3]. The high survival rate observed in Japan may indicate the success of mass screening programs for early cancer detection in situ that can prevent invasive cancer.

Today, public health systems all over the world are making progress in treating $\mathrm{H}$. pylori, one of the key factors predisposing to GC, and raising health awareness among the population. Owing to health education, the mortality from GC declines by $3 \%$ annually in many countries, including Russia [1].

This review discusses over 100 meta-analyses of cohort and case-control studies investigating associations of exogenous and endogenous factors with the risk of GC, mortality and morbidity from this disease. The literature search included articles published within the past 7 years, but significant findings from earlier publications relevant to the subject are 
also mentioned in the review. In addition, the review addresses possible associations between GC and hereditary syndromes, genetic polymorphisms and occupational hazards. The majority of gastric malignancies are adenocarcinomas. Many meta-analyses differentiate between adenocarcinomas in the gastric cardia and non-cardia cancers. Therefore, unless otherwise specified, in this paper gastric cancer will refer to adenocarcinomas with specific localizations.

\section{High-risk factors for GC}

\section{Diet}

A study of dietary habits conducted in 191 patients with gastric cardia cancer, 190 patients with non-cardia cancer and 222 healthy controls established a statistically significant correlation between the risk of GC and dietary habits, including irregular meals, overeating and insufficient mastication: odds ratios (OR) were 4.2 (95\% confidence interval (CI): 2.3-7.7), 4.7 (2.1-10.8) and 7 (1.3-5.3), respectively [4].

\section{Meat consumption}

A diet rich in meat (over $160 \mathrm{~g} /$ day) contributed to the cumulative risk of GC in the main group (obesity, high body mass index (BMI), consumption of hot tea and high-fat foods). First, the risk of GC was found to vary depending on the type of consumed meat. A direct $(\mathrm{OR}=1.87(95 \% \mathrm{Cl}: 1.01-3.47))$ and negative $(\mathrm{OR}=0.36$ (95\% Cl: 0.19-0.68)) correlations were established between the risk of GC and the consumption of red and white meats, respectively. In the cited publication, beef, lamb, sausages, and hot-dogs were defined as red meat, whereas white meat referred to fish and poultry. Fish is rich in polyunsaturated fatty acids, therefore $\mathrm{N}$-nitroso compounds are less likely to form as fish cooks; this prevents carcinogenesis [5]. Second, frying and charcoal grilling were associated with increased risk of GC due to the formation of carcinogens: OR $1.9(95 \% \mathrm{Cl}$ : 1.0-3.6) and OR 1.8 (95\% Cl: 1.3-2.6), respectively [6]. Thus, excessive consumption of fried or grilled red meat that can potentially contain heterocyclic amines, $\mathrm{N}$-nitroso compounds and polycyclic aromatic hydrocarbons is reliably linked to the risk of GC and increases the risk of colorectal cancer (CC) by $20-50 \%$ [7, 8]. Obviously, the risk of GC can be lowered by choosing a safer cooking technique and enriching the diet with nitrosation inhibitors, such as vitamins C, E, phenolic and other bioactive compounds extracted from fresh vegetables and fruits. For the European population, the lack of fresh vegetables and fruits in the diet is a significant factor promoting the risk of GC, similar to the consumption of smoked meat products (bacon, sausages and ham) [9]. Besides, excessive intake of cholesterol with animal source foods was correlated with the increased frequency of malignancies, including GC [10].

\section{Excessive salt consumption}

Although salt (sodium chloride) is important for normal metabolism, it has adverse systemic effects when ingested in excess. Sodium chloride stimulates secretion of gastric juice, thereby accelerating DNA synthesis and cell proliferation and leading to atrophic gastritis [9]. According to some researchers, the chronic form of this disorder may provoke GC. In other words, excessive salt consumption provokes GC. A metaanalysis of prospective cohort studies concluded that high and moderate salt intakes (as opposed to low intake of $<5 \mathrm{~g} /$ day) were significantly associated with elevated risk of GC: OR 1.68
(95\% Cl: 1.17-2.41) and OR 1.41 (1.03-1.93), respectively [11]. Another study conducted in 422 patients with GC and 649 community controls assessed the role of high-salt diet (corrected for the presence H. pylori infection, smoking status, tumor site and histological type) as an independent risk factor for GC. The study found that individuals who added salt at the table were at greater risk for $\mathrm{GC}(\mathrm{OR}=2.01$ (95\% Cl: 1.16-3.46)) as early as within a year before the onset of cancer symptoms [12]. Two more systematic reviews provide convincing evidence that excessive salt consumption (> 5-6 g/day) is associated with elevated risk for GC $[13,14]$.

\section{Pickles}

Pickles are traditional components of many cuisines. They contain high amounts of preservatives, including salt, acetic and benzoic acid, diphenyls, and nitrates. Can pickles increase the risk of GC? Regular consumption of pickled vegetables in an East Asian population was associated with heightened risk of $\mathrm{GC}$ in comparison with the control group (no pickles in the diet). According to the meta-analysis, the cumulative OR was 1.52 (95\% Cl: 1.37-1.68); for case-control studies OR was 1.56 (95\% Cl: 1.39-1.75); for cohort studies, OR was 1.32 (95\% Cl: 1.10-1.59) [14]. Similarly, another publication reported a high risk of GC in individuals who included pickled vegetables in their diet $(\mathrm{OR}=5.5(1.4-19.5))$ [15].

\section{Nitrates}

Nitrates accumulated in crops and drinking water (> $20 \mathrm{mg} / \mathrm{L}$ ) negatively affect human health. Ingesting high amounts of nitrates was correlated with increased risk of GC and death from this disease [16].

\section{Dietary fat}

A study reported an association between $\mathrm{GC}$ and increased consumption of vegetable oil ( $\mathrm{OR}=4.5$ (95\% Cl: $1.00-20.17)$; $p=0.03)$ and lard $(\mathrm{OR}=1.4(95 \% \mathrm{Cl}$ : 0.63-3.01) for the population of South-East Asia [17]. Perhaps, the specific effects of vegetable oils on carcinogenesis may be explained by their chemical composition. For example, the well-known Mediterranean diet, in which olive oil is the central ingredient, reduces the risk of some cancers. This effect is attributed to monounsaturated oleic acid, which inhibits the overexpression of the HER2 (Her-2/neu, erbB-2) oncogene; such inhibition is particularly important in breast cancer [18]. However, the intake of trans fats, including hydrogenated fish oil, is correlated with increased GC morbidity ( $p=0.01$ ) [19].

\section{Regular coffee consumption}

The effects of regular coffee consumption on the neoplastic transformation in the gastrointestinal tract are an interesting research object. The relative risk (RR) of GC was 0.94 (95\% Cl: 0.80-1.10) for individuals who drank 3-4 cups of coffee a day vs. $R R=0.93(95 \% \mathrm{Cl}: 0.88-0.99)$ for those who drank 1-2 cups of coffee, in comparison with the control group (zero coffee consumption). After the correction by design, sex, duration of observation and population, a statistically significant difference was discovered between coffee consumption and diminished risk of $\mathrm{GC}(\mathrm{RR}=0.85(95 \% \mathrm{Cl}: 0.77-0.95$; case-control studies) [20]. However, the opposite results were generated by another analysis of subgroups stratified by sex, region and time, revealing increased risk for $\mathrm{GC}(\mathrm{RR}=1.36(95 \% \mathrm{Cl}$ : 
1.06-1.75)) [21]. Frequent, long-term coffee consumption is likely to be both a risk factor and an anti-risk factor for GC.

\section{Hot meals and hot drinks}

A case-control study included 600 cases of esophageal squamous-cell carcinoma (ESCC), 599 cases of gastric cardia carcinoma (GCA), 316 cases of gastric non-cardia adenocarcinoma (GNCA) and 1,514 controls. The risk of cancer rose by $150-219 \%$ in patients who had hot foods every day in comparison with those who rarely or never had their meals hot [22]. Another risk factor for GC was hot tea $(p<0.05)$ [23].

\section{High intake of simple carbohydrates}

Food products with a high glycemic index (Gl) can increase the risk of cancer as they modulate the levels of insulin-like growth factor 1 (IGF1) associated with diabetes. High-carb diets were shown to be strongly associated with heightened risk of colon cancer and diabetes, but did not contribute to the incidence of GC [24].

\section{Lifestyle}

\section{Alcohol and smoking}

Regular smoking is recognized as a significant risk factor for $\mathrm{GC}$ in men (RR $=1.62(95 \% \mathrm{Cl} 1.50-1.75))$ and women ( $R R=1.20$ (95\% Cl: 1.01-1.43)). The risk for this cancer increases from 1.3 (for occasional smokers) to 1.7 for those who smoked 30 cigarettes a day; the long history of smoking raises the risk of gastric cardia and non-cardia cancers: $R R=1.87$ (95\% Cl: 1.31-2.67) and 1.60 (95\% Cl: 1.41-1.80), respectively [25], with $\mathrm{OR}=1.9(95 \% \mathrm{Cl}: 0.85-4.50)$ [17]

A few publications reported the overall negative effect of alcoholic beverages on the development of GC. The metaanalysis of 75 studies [26] revealed that alcohol consumption was considerably associated with the risk of gastric non-cardia $(\mathrm{OR}=1.19(95 \% \mathrm{Cl}: 1.01-1.40) ; p=0.033)$ and cardia cancers (OR $=1.6$ (95\% Cl: 0.98-1.39); $p=0.087$ ). The relative risk of GC for heavy beer/wine drinkers, in comparison with those who drank little alcohol, was 1.13 (95\% Cl: 1.03-1.24; $p=0.012)$ and 0.99 (95\% Cl: $0.84-1.16 ; p=0.857)$, respectively [26]. When adjusted for smoking, education and BMI, the risk of GC was 2.00 (95\% Cl: 1.04-3.82) for regular alcohol drinkers (2-7 times a week) vs. those who consumed alcoholic beverages only occasionally (a few times a year); the risk for GC was 1.90 (95\% Cl: 1.13-3.18) for individuals consuming $\geq 100.0 \mathrm{~g}$ ethanol a week. The odds ratio for death from GC for men who consumed $\geq 0.5 \mathrm{~L}$ vs. $<0.5 \mathrm{~L}$ of alcohol per occasion was 2.95 (95\% Cl: 1.30-6.68) [27]. High alcohol consumption (>60 $\mathrm{g} /$ day vs. 0.1-4.9 g/day) was associated with increased mortality from GC (1.65; 95\% Cl: 1.06-2.58). Beer consumption over $\geq$ $30 \mathrm{~g}$ of alcohol/day was associated with increased GC morbidity (1.75 (95\% Cl: 1.13-2.73)); however, there was no significant association with wine or liquor consumption [28].

Thus, the risk of GC was minimal or zero for individuals who consumed moderate amounts of wine. A possible explanation is that extractives contained in wine (like the polyphenolic compound resveratrol) exert a broad spectrum of favorable effects: antioxidant, anti-inflammatory and anti-carcinogenic [29].

\section{Opium consumption}

A 4-year-long prospective cohort study was carried out in 50,045 participants, of whom $17 \%$ were long-term opium users with an average history of opium smoking or ingestion of 12.7 years. The study found that the risk of death from gastrointestinal cancer (GIC) was 1.55 (95\% Cl: 1.24-1.93) for all subjects. During the observation period, 387 people died of GIC; cancer-associated mortality in the group of opium users was 2.21 times higher (95\% Cl: 1.57-3.31) and also dose-dependent [30]. Other authors report an association between opium use and elevated risk of cardia and non-cardia adenocarcinomas (OR $=3.1$ (95\% Cl: 1.9-5.1)). Similar to the previous cited study, they point to the dose-dependent effect $(\mathrm{OR}=4.5$ (95\% Cl: 2.3-8.5)) [31].

\section{Sleep duration}

The meta-analysis of 25 articles (a total of 1,550,524 participants and 86,201 GC cases) revealed that neither short nor long sleep duration (relative to the baseline value of $7 \mathrm{~h}$ ) was associated with increased risk of cancer [32]. A prospective cohort study, which recruited 173,327 men and 123,858 women aged 51-72 years, reported a significant risk of death from GC in men (1.29 (95\% Cl: 1.05-1.59); $p=0.03)$ who normally slept $5-6 \mathrm{~h}$ vs. $7-8 \mathrm{~h}$ a day. By contrast, women who normally shad $5 \mathrm{~h}$ of sleep per day were at reduced risk of death from GC $(0.76(0.24-2.41))$. It should be noted that the average weighted risk of other cancers did not significantly correlate with variations in sleep duration relative to the control group [33]; these findings were consistent with the results of other studies [34].

\section{Chronic stress}

There is a known psychosomatic link between the level of stress and gastritis (or gastric/duodenal ulcers) [35]; these conditions, together with co-existing inflammation, can predispose to neoplasms [36]. Stress aggravates gastric cancers; the underlying molecular mechanism of this phenomenon was studied in [37]. According the study, the expression of the $\beta_{2}$-adrenergic receptor (ADRB2) was elevated in gastric tumors and positively correlated with their size, stage and spread to lymph nodes. Induced by the stress hormone, the activation of the ADRB2 signaling pathway played the key role in the progression of cancer and metastasis. This suggests that GC progression may be regulated by the drugs for $\beta_{2}$ blockade (propranolol) as an adjunct to existing therapies [37].

\section{Pharmacotherapy}

\section{Nonsteroidal anti-inflammatory drugs and aspirin}

This class of drugs includes selective cyclooxygenase-2 (COX-2) inhibitors that, according to some studies, reduce the risk of GC and hold potential for chemoprevention [38]. Still, many aspects of their use, such as optimal dosing and therapy duration, remain understudied. Perhaps, the inhibitory effect of NAIDs on carcinogenesis stems from their ability to induce apoptosis of epithelial cells and regulate angiogenesis via COX2-dependent and COX-2-independent signaling pathways [39]. A population case-control study enrolled individuals aged 30-79 years with esophageal adenocarcinoma $(n=293)$, esophageal squamous-cell carcinoma ( $n=221$ ), gastric non-cardia cancer $(n=368)$ and gastric cardia cancer $(n=261)$. The control group comprised 695 participants. Prolonged aspirin therapy over the course of 2 to 5 years reduced the risk of such cancers: $\mathrm{OR}=0.37$ (95\% Cl: 0.24-0.58), 0.49 (95\% Cl: 0.28-0.87), 0.46 (95\% Cl: 0.31-0.68), respectively, in comparison with the 
control group (no aspirin), except cardia cancer $(\mathrm{OR}=0.80$ (95\% Cl: 0.54-1.19)) [40].

\section{Statins}

The association between blood cholesterol levels and the risk of GC is debatable. Statins inhibit endogenous cholesterol synthesis and are traditionally used to treat metabolic disorders; in addition, they can exert anticancer activity [41]. The metaanalysis of 26 randomized control and 8 observational studies of over $7,000 \mathrm{GC}$ cases demonstrated that statins reduced the risk of $\mathrm{GC}$ by an average of $30 \%(\mathrm{RR}=0.73(95 \% \mathrm{Cl}$ : 0.58-0.93)) [42].

\section{Chronic diseases}

\section{Gastroesophageal reflux disease}

Many studies have established a significant association between GERD and the risk of gastric cardia cancer [43, 44]. In most studies, GERD was associated with a 2- to 5-fold increase in GC morbidity. At the same time, some studies reported the lack of or the negative association between GERD and noncardia gastric cancer [43-45]

\section{Metabolic syndrome}

Disrupted metabolism may be an additional risk factor for different cancer types and affect the overall survival of cancer patients. A retrospective study analyzed the clinical and histological data of 808 patients with GC and a history of metabolic syndrome (MS). The control group consisted of 1,146 individuals. Main group patients had high blood levels of triglycerides $(p=0.007)$, lower levels of high-density lipoproteins (HDL) $(p<0.001)$, a higher frequency of hypertension disease $(p<0.001)$ and diabetes $(\mathrm{OR}=1.86$ (95\% Cl: 1.39-2.48)). MS was associated with poorly differentiated gastric carcinoma and late progression to advanced stages according to the TNM classification [46].

Type 2 diabetes mellitus is the most common endocrine disorder characterized by hyperglycemia due to deficient insulin secretion and impaired metabolism. A few clinical studies investigated a causal link between diabetes and cancer. At least two studies showed that patients with diabetes mellitus were at greater risk for hepatic, pancreatic, gastric, colon, renal and breast cancers $[47,48]$. According to a prospective cohort study, there was an association between early GC onset and hyperglycemia ( $p=0.000 ; \mathrm{OR}=1.066)$, insulin resistance $(p=0.024 ; \mathrm{OR}=1.084)$, glycated hemoglobin $(\mathrm{HbA} 1 \mathrm{c})$ levels $(p=0.004 ; \mathrm{OR}=3.225)$, and low total blood cholesterol $(p=0.005 ; \mathrm{OR}=1.015)$. Besides, there was no significant association between the risk of early GC onset and the levels of the insulin-stimulated hormone adiponectin in the blood [49]. Hyperglycemia (glucose concentrations $\geq 5.3 \mathrm{mmol} / \mathrm{L}$ ) contributed to the risk of GC associated with $\mathrm{H}$. pylori infection [50]. It was discovered that $\mathrm{HbA} 1 \mathrm{c}$ concentrations $\geq 6.0 \%$ (42 mmol/L) adjusted for sex, age and H. pylori seropositivity were a statistically significant factor predisposing to GC [50]. Likewise, an association was confirmed between the poor survival of GC patients ((1.73 (95\% Cl: 1.08-2.79) and the risk of death from gastric cardia cancer (3.40 (95\% Cl: 1.45-7.97)) in the setting of type 2 diabetes mellitus. $\mathrm{HbA} 1 \mathrm{C}$ concentrations $\geq 6.0 \%$ (42 mmol/L) were the endogenous marker of increased mortality from GC (1.68 (95\% Cl: 1.07-2.63)) [51].

There is no firm association established between the levels of blood cholesterol and the risk of GC because the data generated by case-control vs. cohort studies are conflicting [52]. Nevertheless, high cholesterol should not be ignored if a patient is exposed to other risk factors for GC. The multivariate analysis of variance suggested a statistically significant association between the risk of gastric dysplasia (corrected to age and sex) and the levels of glucose of 100-125 mg/100 ml $(R R=2.261 ; 95 \%$ Cl: 1.147-4.457); total cholesterol $\geq$ $240 \mathrm{mg} / 200 \mathrm{ml}(\mathrm{RR}=6.299 ; 95 \% \mathrm{Cl}: 1.277-31.076) ; \mathrm{LDL}$ of 130-159 mg/100 ml (RR = 0.250; 95\% Cl: 0.069-0.903), and $\mathrm{MS}(\mathrm{RR}=2.177 ; 95 \% \mathrm{Cl}: 1.082-4.379)$ [53].

\section{Obesity}

Recently, obesity has become a public health priority due to the growing incidence of cancers reliably associated with this condition. Globally, obesity-associated malignancies account for $11.9 \%$ of cancers in men and $13.1 \%$ of cancers in women. There is evidence that excess body weight may increase the risk of 13 different cancers, including endometrial, esophageal, renal, pancreatic, hepatocellular, gastric cardia, colorectal, ovarian, thyroid, bladder, and postmenopausal breast cancers meningiomas and multiple myelomas [54]. It is emphasized that abdominal obesity is a significant risk factor for GC [52, 55-57]. After adjustment for age, alcohol consumption, smoking, family history and total blood cholesterol, BMl from 27.5 to 29.9 was associated with the risk of grade 3 gastric dysplasia in men $(\mathrm{OR}=1.87 ; 95 \% \mathrm{Cl}:=1.24-2.81)$ and women $(\mathrm{OR}=2.72$; $95 \% \mathrm{Cl}$ : 1.44-5.16). For men with $\mathrm{BMl}$ from 27.5 to 29.9, the risk of developing gastric cardia dysplasia was $\mathrm{OR}=1.78(95 \% \mathrm{Cl}: 1.02-3.10)$; for $\mathrm{BMI} \geq 30.0 \mathrm{OR}$ was 2.54 (95\% Cl: 1.27-5.08); for women with BMl of 27.5-29.9 OR was 2.88 (95\% Cl: 1.27-6.55) and for women with $\mathrm{BMI} \geq 30.0$ OR was 2.77 (95\% Cl: 1.36-5.64) [52]. The analysis of 2,130 cancer cases from the sample of 913,182 patients showed that obesity increased the risk of gastroesophageal cancer and GC by $49-68 \%$ and $33-48 \%$, respectively [57].

\section{Autoimmune disorders}

Autoimmune disorders may be regarded as an alternative etiological factor for chronic inflammation of gastric mucosa, promoting the risk of carcinogenesis. A systematic review of 52 observational studies discovered an association of some autoimmune diseases with the risk of $\mathrm{GC}(\mathrm{OR}=1.37$; $95 \% \mathrm{Cl}$ : 1.24-1.52) [58]. Specifically, a significant link was established between GC and the following disorders: dermatomyositis $(\mathrm{OR}=3.69 ; 95 \% \mathrm{Cl}: 1.74-7.79)$, pernicious anemia $(\mathrm{OR}=2.84$; 95\% Cl: 2.30-3.50), Addison's disease (OR $=2.11 ; 95 \% \mathrm{Cl}$ : 1.26-3.53), dermatitis herpetiformis $(\mathrm{OR}=1.74 ; 95 \% \mathrm{Cl}: 1.02-$ 2.97), IgG4-related disease ( $\mathrm{OR}=1.69 ; 95 \% \mathrm{Cl}: 1.00-2.87)$, primary biliary cholangitis $(\mathrm{OR}=1.64 ; 95 \% \mathrm{Cl}: 1.13-2.37)$, type 1 diabetes mellitus (OR $=1.41 ; 95 \% \mathrm{Cl}: 1.20-1.67)$, systemic lupus erythematosus $(\mathrm{OR}=1.37 ; 95 \% \mathrm{Cl}: 1.01-1.84)$ and Graves' disease (OR $=1.27$; 95\% Cl: 1.06-1.52) [58].

\section{Infection}

\section{Helicobacter pylori}

Corrected for other risk factors, Helicobacter pylori infection has a critical role in the etiology and early onset of GC [59]. Patients seropositive for $\mathrm{H}$. pylori and prone to excessive salt consumption were at a 10 times higher cumulative risk for GC than the control group (no antibodies to $H$. pylori and low-salt diet). H. pylori infection was shown to aggravate GC prognosis 
in patients with a family history of cancer and smokers [60]. Interesting observations were described in a study that reported an association between the Lewis antigen system and the risk of GC [61]. The frequency of the Lea+b- phenotype was higher in patients with $\mathrm{GC}$ and $H$. pylori infection; the risk of GC was 3.15 times higher in the carriers of this phenotype than in those with the Lea- $b^{+}$phenotype [61]. Another metaanalysis that summarized the data generated by 22 studies demonstrated that patients who had undergone $H$. pylori eradication therapy were at lower risk for GC than those who had not $(0.53 ; 95 \% \mathrm{Cl}$ : 0.44-0.64). Eradication of $\mathrm{H}$. pylori ensured a stable therapeutic effect for asymptomatic infected individuals (0.62; 95\% Cl: 0.49-0.79) and patients who had undergone the endoscopic resection of GC $(0.46 ; 95 \% \mathrm{Cl}$ : $0.35-0.60)$ [62].

\section{Human papillomavirus}

There are causal links between human papillomavirus (HPV) infection and GC. The meta-analysis of 30 studies $(1,917$ cases and 576 controls) found that the prevalence of HPV among the patients with GC was 28.0\% (95\% Cl: 23.2-32.7; $p<0.001)$ and established an association between the infection and the risk of $\mathrm{GC}(\mathrm{OR}=7.388 ; 95 \% \mathrm{Cl}$ : 3.876-14.082; $p=0.004)$. According to the analysis of 15 case-control studies, HPV 16 was diagnosed in patients with GC 3 times more often than HPV 18. The researchers concluded that HPV may play a role in the pathogenesis of GC; more solid evidence can be obtained by isolating HPV from precancerous cells of gastric dysplasia lesions or and adenomas [63]

\section{Epstein-Barr virus}

About $90 \%$ of the population are infected with the EpsteinBarr virus (EBV). The virus was isolated from a variety of tumors, including nasopharyngeal and gastric cancers, Burkitt, Hodgkin and non-Hodgkin lymphomas. Today EBV infection is thought to be a potential risk factor for cancer. A correlation was established between the seropositivity for EBV and the nasopharyngeal cancer/Hodgkin lymphoma [64]. However, only $7-10 \%$ of gastric tumors were associated with EBV [64]; according to the authors of the analysis, this might be due to small sample sizes. For example, seropositivity for EBV was not associated with elevated risk of GC in the main and control groups that comprised 185 and 200 cases, respectively. High antibody titers for the Epstein-Barr nuclear antigen were associated with longer survival in patients with cardia cancer [65]. In another retrospective study (54 individuals with gastric adenocarcinomas), the risk of cancer in patients seropositive for IgA against the viral capsid protein and IgG against the early antigen R-component was 4 and 2 times higher, respectively, than in the control group. Antibody titers against EBV were significantly higher in patients who were later diagnosed with EBV-associated GC than in those with GC not associated with EBV infection [66].

These findings suggest that the failure of the immune system to control EBV infection may increase the risk of malignancies in the long term [66]. According to the published study of the associations between GC and a coinfection with 3 pathogens ( $H$. pylori, HPV and EBV) [67], the GC specimens contained the nucleic acids of $H$. pylori, EBV and HPV in 87, 20 and 3\% of cases, respectively. $H$. pylori was mainly represented by the $\operatorname{cag}^{+}\left(H\right.$. pylori - cag $\left.A^{+}\right)$strain. The cagA gene encodes the virulence factor, which is essentially an oncogenic protein capable of causing hyperplasia of the gastric epithelium and polyposis. A coinfection with $H$. pylori-cagA $A^{+}$and EBV was correlated with advanced stages of GC, and the presence of EBV infection was correlated with distant metastasis [67]. Consequently, measures for $\mathrm{H}$. pylori and EBP prevention help to ward off GC and especially its aggressive forms.

\section{lonizing radiation}

The literature analysis shows that the association between the risk of GC and ionizing radiation doses remains understudied. Exposure to both natural or man-made sources of radiation (accidents at nuclear power stations) can cause multiple damage to human genes and induce shifts in the global gene expression [68].

Some secondary tumors can be provoked by radiation therapy for the abdomen. The cumulative coefficient of primary GC incidence in the studied group (22,269 subjects) was $1.45 \%$ 30 years after the diagnosis. Individuals who received radiation therapy for testicular cancer were at a 6-times higher risk of developing $\mathrm{GC}(\mathrm{OR}=5.9 ; 95 \% \mathrm{Cl}: 1.7-20.7)$. The risk grew with the total dose approaching 50 Gy $(p<0.001)$, OR $=20.5$ (3.7-114.3) in comparison with the total dose of $<10$ Gy. Thus, the highest risk of developing secondary cancers was observed for the total radiation dose of $>30$ Gray [69]. It should be noted that in its latent state, EBV associated with GC expresses a very small number of genes. However, exposure to ionizing radiation leads to the NF-кB-mediated activation of the lytic form of the virus, whose persistence is an additional risk factor for GC [70].

\section{Occupational hazards}

Exogenous factors predisposing to GC include social factors and occupational hazards. For example, an association was discovered between the heightened risk of GC quantitatively expressed as the relative indexes of inequality and a few social factors [71], such as low educational status $(2.97$ (95\% Cl: 1.92-4.58)), job (4.33 (95\% Cl: 2.57-7.29)), socioeconomic status (SES) (2.64 (95\% Cl: 1.05-6.63)), and income (1.25 (95\% Cl: 0.93-1.68)). Differences in GC incidence between social groups were more pronounced in another study [72] showing that the risk of GC decreased from $22.7 \%$ to $2 \%$ $(p<0.001)$, from $12 \%$ to $0.5 \%(p<0.001)$ and from $6.5 \%$ to $0.1 \%(p<0.001)$ in the groups with low, moderate and high SES. A significant correlation was observed between low SES and GC incidence and mortality [73]. According to the metaanalysis of 25 studies (9,773 GC cases and 24,373 controls), the risk of GC decreased in groups with a high educational status: OR and the relative index of inequality were $0.60195 \%$ Cl: 0.44-0.84) and 0.45 (95\% Cl: 0.29-0.69), respectively [73].

Stratification of occupational hazards in a Swedish population revealed an almost two-fold difference in the risk of GC between different socio-economic groups [74]. Individuals involved in manual labor (miners, quarry workers, fishermen, construction workers, packers, loaders, warehouse workers, clerical workers, nurses and postmen) were at higher risk for GC [74]. Standardized incidence ratios of gastric cardia cancer were significantly increased for male gardeners, transport workers, chemical industry workers and bricklayers. Cement and mineral dusts were the main occupational risk factor for GC [74].

In a Spanish population, the risk of developing GC was statistically significant for male cooks $(\mathrm{OR}=8.02)$, wood processing plant operators $(O R=8.13)$, food and related product machine operators $(\mathrm{OR}=5.40)$, miners and quarry workers (OR $=4.22 ; 95 \% \mathrm{Cl}$ : 0.80-22.14)) [75]. The risk of GC was also significant for men and women involved in plant 
cultivation and exposed to pesticides (OR $=10.39 ; 95 \% \mathrm{Cl}$ : 2.51-43.02), as well as for those involved in manufacturing and exposed to asbestos (OR $=3.71 ; 95 \% \mathrm{Cl}: 1.40-9.83)$ and wood dust $(\mathrm{OR}=3.05)$ [75].

$\mathrm{Cr}(\mathrm{VI})$ is an established carcinogen provoking lung cancer. The meta-analysis of 56 cohort and 74 case-control studies sought to test the hypothesis about the association between the risk of GC and occupationally inhaled chromium in chrome plating and leather workers and those exposed to Portland cement [76]. The cumulative relative risk was 1.27 (95\% Cl: 1.18-1.38); in comparison with other studies reporting the increased risk for lung cancer, RR for GC was 1.41 (95\% Cl: 1.18-1.69) [76]. On the whole, these results allow identifying $\mathrm{Cr}(\mathrm{VI})$ as a risk factor for $\mathrm{GC}$.

Genetic factors for GC: hereditary cancer syndromes and genetic polymorphism

\section{Hereditary GC syndromes and family history}

The family history of GC is another factor that augments the risk of the disease 1.5-3.5 fold if at least one first-degree relative has GC [77]. Although GC is mostly sporadic, familial aggregation is observed in about $10 \%$ of cases and $1-3 \%$ of cases are associated with cancer syndromes [78, 79]. According to a study, the incidence of GC was higher in individuals whose relatives had a history of early-onset GC (before 50 years) $[80,81]$. The frequency of GC was higher among patients whose first-degree relatives had $\mathrm{GC}(\mathrm{OR}=2.7$; $95 \% \mathrm{Cl}: 1.7-4.3)$. If two or more relatives had GC, OR rose to 9.6 (95\% Cl: 1.2-73.4) [82]. The incidence of GC was also higher in patients whose first/second degree relatives had a history of malignancies including GC, breast or lung cancer, gynecological and hematologic cancers, as shown by the long-term observations of the main group ( $n=44 ; 54.5 \%$, $p<0.01)$ and the control group ( $n=44 ; 11.4 \%, p<0.01)$ [79]. It is reported that GC-associated mortality was higher in patients with a family history of $H$. pylori and $\mathrm{GC}(\mathrm{OR}=8.2$; 95\% Cl: 2.2-30.4) than in the control group (no family history of $H$. pylori and GC). At the same time, non-cardia cancer was the most common malignancy in the sample [83].

The most significant hereditary cancer syndrome manifested as $\mathrm{GC}$ is hereditary diffuse gastric cancer (HDGC). This syndrome is associated with pathogenic variants of the $\mathrm{CDH} 1$ gene, which encodes the cell adhesion protein E-cadherin. A study conducted in 75 families found that the cumulative risk of GC was $70 \%$ and $56 \%$ for female and male carriers of the pathogenic $\mathrm{CDH} 1$ variants, respectively, by the age of 80 years [84]. An earlier study involving 13 families produced the opposite results: the cumulative risk of GC was $67 \%$ for men and $83 \%$ for women [85]. It should be noted that the cited study included 3 Maori and one Pakistani families. Thus, ethic differences should be accounted for when estimating the cumulative risk of HDGC. Besides, both publications show that female carriers of the pathogenic $\mathrm{CDH} 1$ alleles are at increased risk for lobular breast cancer (cumulative risk of $39-42 \%$ by age of 80 years). Importantly, the pathogenic $\mathrm{CDH} 1$ variants are detected in only $40 \%$ of patients with clinical signs of HDGC. Genetic causes of this disease in other patients are obscure [86].

Another hereditary cancer syndrome contributing to the risk of GC is the Peutz-Jeghers syndrome. It is characterized by the development of gastrointestinal hamartomatous polyps. Its distinctive feature is the presence of melanin spots on the lips, buccal mucosa and other parts of the body. The disease is manifested as gastrointestinal tumors, including GC. The affected women are at increased risk for breast cancer. The disease is caused by the pathogenic variants of the STK11 gene [87]. According to some estimates, the cumulative risk of GC in patients with the Peutz-Jeghers syndrome aged 15 to 64 years is $29 \%$ [88].

Another syndrome that significantly increases the risk of GC is juvenile polyposis. This condition is caused by the pathogenic mutations in the SMAD4 or BMPR1A genes. As a rule, juvenile polyposis affects children but can also arise at older age. The cumulative risk of GC is $21 \%$ for patients afflicted with this syndrome [89].

Among other hereditary cancer syndromes that aggravate the risk of GC are Lynch syndrome, Li-Fraumeni syndrome, familial adenomatous polyposis, MYH-associated polyposis, gastric adenocarcinoma and proximal polyposis of the stomach [86]. There is evidence that patients with ataxia-telangiectasia, Bloom syndrome, Cowden syndrome, and xeroderma pigmentosum are at increased risk for GC [89].

Another condition worth mentioning is the syndrome of hereditary breast and ovarian cancers associated with mutations in the BRCA1 and BRCA2 genes. Carriers of the pathogenic BRCA1/BRCA2 alleles are at increased risk for GC [90, 91]. Although this risk is only slightly increased, the syndrome is very common and therefore its association with GC may be clinically significant.

In addition to the listed hereditary cancer syndromes (see Table), the risk of GC is elevated in patients with inherited primary immunodeficiency [92]. Recently, the incidence of GC among such patients has started to decline; this might be tied to the spread of $H$. pylori eradication therapy [93].

\section{Genetic polymorphism}

It is not only the pathogenic variants of nucleotide sequences associated with cancer syndromes that contribute to the risk of developing GC, but also non-pathogenic populational polymorphisms. According to one of the largest research studies of twins conducted in Sweden, Denmark and Finland, the contribution of genes to $\mathrm{GC}$ is much greater than to other nosologies. The risk of GC for a male monozygotic twin of a twin with GC was 9.9 times higher than for a male monozygotic twin of a twin without GC. Concordance for GC in male monozygotic twins was 0.08 , i.e. there is an $8 \%$ probability of GC in one of the twins if the other already has GC [94].

According to a 2019 meta-analysis that covered 186 studies, the strongest associations were observed for 9 variants of 9 genes: APE1 rs1760944, DNMT1 rs16999593, ERCC5 rs751402, GSTT1 0/0 genotype, MDM2 rs2278744, PPARG rs1801282, TLR4 rs4986790, IL-17F rs763780 and CASP8 rs3834129. The metanalysis included a total of 61 gene variants [95]. The strongest association with GC was shown for the $\mathrm{G}$ allele of the APE1 gene (rs1760944): OR was 1.77 [95]. The existing data on the associations between genetic polymorphisms and GC are not clinically relevant and cannot be used to elaborate screening recommendations. So, it is more reasonable to focus on the family history while estimating the risk of GC.

\section{Factors reducing the risk of GC}

\section{Fruits and vegetables}

By and large, diets enriched in fruits and vegetables (especially fresh) were negatively correlated with the risk of GC [4, 9]. Regular intake of fruits and vegetables reduced the risk of GC by 
Table. Hereditary cancer syndromes associated with increased risk of GC

\begin{tabular}{|l|c|c|c|c|}
\hline \multicolumn{1}{|c|}{ Syndrome } & Genes & GC risk & Inheritance pattern & Reference \\
\hline Hereditary diffuse GC & CDH1 & $56-83 \%$ & Autosomal-dominant & {$[84,85]$} \\
\hline Peutz-Jeghers syndrome & STK11 & $29 \%$ & Autosomal-dominant & {$[86]$} \\
\hline Juvenile polyposis & SMAD4, BMPR1A & $21 \%$ & Autosomal-dominant & {$[86]$} \\
\hline Lynch syndrome & $M L H 1, M S H 2$, MSH6, PMS2, EPCAM & $1-13 \%$ & Autosomal-dominant & {$[86]$} \\
\hline Li-Fraumeni syndrome & TP53 & $2,8 \%$ & Autosomal-dominant & {$[86]$} \\
\hline Familial adenomatous polyposis & APC & $1-2 \%$ & Autosomal-dominant & {$[86]$} \\
\hline Hereditary breast and ovarian cancers & BCRA1, BRCA2 & Increased & Autosomal-dominant & {$[86]$} \\
\hline MYH-associated polyposis & MYH & Increased & Autosomal-recessive & {$[86]$} \\
\hline $\begin{array}{l}\text { Gastric adenocarcinoma and } \\
\text { proximal polyposis }\end{array}$ & Pathogenic variant of APC promoter & Increased & Autosomal-dominant & {$[86]$} \\
\hline Ataxia-telangiectasia & ATM & Likely increased & Autosomal- recessive & {$[89]$} \\
\hline Bloom syndrome & BLM & Likely increased & Autosomal- recessive & {$[89]$} \\
\hline Cowden syndrome & PTEN & Likely increased & Autosomal-dominant & {$[89]$} \\
\hline Xeroderma pigmentosum & ERCC5, POLH, XPA, XPC & Likely increased & Autosomal- recessive & {$[113]$} \\
\hline
\end{tabular}

48-70\% and 46-68\%, respectively [22], which was consistent with the findings of another research study $(\mathrm{OR}=0.3 ; 95 \% \mathrm{Cl}$ : $0.1-1.0)$ [6]. By contrast, low intake of fruits and vegetables promoted the risk of $\mathrm{GC}(\mathrm{OR}=1.2 ; 95 \% \mathrm{Cl}$ : 0.74-1.96) [17]. Onions and garlic had a protective effect on the gastrointestinal tract and reduced the risk of GC [96]. A negative association was established between the risk of $\mathrm{GC}$ and consumption (often vs never) of garlic stalks ( $\mathrm{OR}=0.30 ; 95 \% \mathrm{Cl}$ : 0.12-0.77). In another study, increased consumption of allium vegetables (onions, garlic, leeks, shallots, garlic stalks, Chinese chives, Welsh onions) reduced the risk of $\mathrm{GC}(\mathrm{OR}=0.54 ; 95 \% \mathrm{Cl}$ : $0.43-0.65)$ [97]. The meta-analysis of 18 studies showed that the relative risks of developing colorectal cancer and GC were 0.69 (95\% Cl: 0.55-0.89) and 0.53 (95\% Cl: 0.31-0.92), respectively, in the main group (garlic consumption $>28.8 \mathrm{~g} /$ week) in comparison with the control group (3.5 g/week) [98].

\section{Dietary fiber intake}

Dietary fiber is a food component that is poorly digested by the gastrointestinal tract of humans but can be fully digested by the intestinal microbiota. A systematic review [99] analyzed 21 publications, to find that the odds ratio of GC for high dietary fiber intake was 0.58 (95\% Cl: 0.49-0.67; $p<0.001)$. Moreover, inclusion of $10 \mathrm{~g}$ of dietary fiber in the diet was associated with a $44 \%$ reduction in the risk for GC [99].

Tea

Similar to coffee, regular tea consumption was also studied for the association with GC. Polyphenolic compounds contained in tea exert antioxidant activity and have a variety of anticancer effects: they inhibit nitrosation and stimulate apoptosis in carcinoma cell lines. About half of the of prospective cohort studies investigating the effect of regular tea consumption on GC did not find any associations between green tea consumption and GC, whereas the rest established a negative association [100].

\section{Dietary carotenoids}

Intake of $\alpha$-, $\beta$-carotins, lycopene, and lutein was negatively correlated with the risk of GC: $\mathrm{OR}=0.59$ (95\% Cl: 0.37-0.92); 0.52 (95\% Cl: $0.46-0.59)$; 0.88 (95\% Cl: $0.55-1.41)$ and
0.85 (95\% Cl: 0.56-1.30), respectively. The RRs of GC at $95 \% \mathrm{Cl}$ were as follows: $0.72(0.50-1.03), 0.79(0.58-1.07)$, $0.80(0.60-1.07)$ and $0.95(0.77-1.18)$, respectively [101]. Thus, case-control studies established a negative correlation between the intake of dietary carotenoids and the risk of GC.

\section{Vitamins}

High vs. low vitamin intake was negatively associated with the risk of GC (RR: 0.78 (95\% Cl: 0.71-0.83)) [102]. However, if daily intake of vitamins was increased 4 times (9 studies), the risk of $\mathrm{GC}$ also increased slightly $(\mathrm{OP}=1.20 ; 95 \% \mathrm{Cl}$ : 0.99-1.44) [102]. The analysis of dose-dependent effects of vitamin A (1.5 mg/day), vitamin C (100 mg/day) and vitamin E (10 mg/day) indicated a decline in the risk of GC by $29 \%$, $26 \%$ and $24 \%$, respectively [102]. Diets high in fruits (100 g/day) rich in vitamin $\mathrm{C}$ were negatively correlated with the risk of GC [9]. Interestingly, intake of food supplements containing garlic extracts, vitamins $\mathrm{C}, \mathrm{E}$ and selenium was associated with reduced morbidity and mortality from GC although the associations were statistically insignificant. By contrast, vitamin therapy was significantly negatively correlated with mortality from esophageal cancer and GC $(0.51 ; 95 \% \mathrm{Cl}$ : 0.30-0.87; $p=0.014)[103]$

Vitamin D, the precursor of the steroid hormone calcitriol, regulates a number of metabolic and signaling pathways in the cells. Low blood levels of vitamin D were shown to correlate with cancer [104]. Spanish patients with GC had low blood concentrations of vitamin $D$, in comparison with the control group (no cancers and vitamin D deficiency): $\mathrm{OR}=8.8(95 \% \mathrm{Cl}$ : $5-22 ; p<0.0001)$ [105]. Case-control studies conducted in the USA demonstrated that both deficiency $(<20 \mathrm{ng} / \mathrm{L})$ and excess (20-29 ng/L) of vitamin D were far more common in patients $(n=103)$ with incomplete gastric metaplasia than in healthy individuals $(n=216)$ with vitamin D concentrations in the blood ranging from 30 to $100 \mathrm{ng} / \mathrm{L}$; this factor might play a role in the development of gastric adenocarcinoma in situ [106]. Sufficient concentrations of vitamin D (over $20 \mathrm{ng} / \mathrm{L}$ ) in the blood plasma of Korean adults were associated with high efficacy of $H$. pylori eradication therapy and low risk of $\mathrm{GC}(\mathrm{OR}=0.57 ; 95 \% \mathrm{Cl}$ : 0.32-1.00) [107].

The link between dietary folic acid (vitamin B9) and GC remains understudied. Studies in mice with induced gastric dysplasia demonstrate that dietary folic acid slows DNA 
hypomethylation in the epithelial cells and stromal myofibroblasts of the stomach associated with worse survival [108]. Besides, folic acid exerts an inhibitory effect on inflammation [108]. Still, the efficacy of folic acid in preventing and treating gastric malignancies is yet to be proved in future research.

\section{Exercise}

Some systematic reviews indicate that regular exercise and sports are usually negatively correlated with the development and relapse of cancer. For example, exercise was associated with a $20-50 \%$ reduction in the risk of lung [109] and breast [110] cancers. The cited reviews discussed a few possible causes underlying this phenomenon: optimization of hormonal status, reduction of oxidative stress in tissue due to oxygen saturation and activation of immune mechanisms. Four studies demonstrated that exercise had a protective effect against gastric cardia cancer $(\mathrm{OR}=0.80 ; 95 \% \mathrm{Cl}$ : 0.63-1.00), and 5 studies showed the same effect against non-cardia cancer
$(\mathrm{OR}=0.63 ; 95 \% \mathrm{Cl}: 0.52-0.76)$, regardless of sex, study quality, study design, and geographic location [111].

\section{CONCLUSION}

Based on the prevailing risk factors for GC described in the review, a few cancer prevention strategies can be singled out, including measures for reducing the risk of primary gastric malignancies, prediction of GC risk using genotyping panels of genetic markers and early detection. Obviously, by changing modifiable behaviors (quitting smoking, reducing salt consumption to $<5 \mathrm{~g} /$ day according to $\mathrm{WHO}$ recommendations, enriching the diet with vegetables, fruits, dietary fibers and antioxidants) one can significantly reduce the risk of developing GC. Special attention should be paid to the detection and treatment of $H$. pylori, which is the primary infectious factor of GC. Eradication therapy for $H$. pylori in patients with diagnosed GC reduces the risk of metachronous recurrence by almost 50\% [112].

\section{References}

1. Ang TL, Fock KM. Clinical epidemiology of gastric cancer. Singapore Med J. 2014; 55 (12): 621-8. DOI: 10.11622/smedj.2014174.

2. Marqués-Lespier JM, González-Pons M, Cruz-Correa M. Current Perspectives on Gastric Cancer. Gastroenterol Clin North Am. 2016; 45 (3): 413-28. DOI: 10.1016/j.gtc.2016.04.002.

3. Isobe $Y$, Nashimoto A, Akazawa K, et al. Gastric cancer treatment in Japan: 2008 annual report of the JGCA nationwide registry. Gastric Cancer. 2011; 14 (4): 301-16. DOI: 10.1007/s10120011-0085-6.

4. Cai L, Zheng ZL, Zhang ZF. Risk factors for the gastric cardia cancer: a case-control study in Fujian Province. World $\mathrm{J}$ Gastroenterol. 2003; 9 (2): 214-8. DOI: 10.3748/wjg.v9.i2.214.

5. Zamani N, Hajifaraji M, Fazel-tabar Malekshah A, Keshtkar AA, Esmaillzadeh A, Malekzadeh R. A case-control study of the relationship between gastric cancer and meat consumption in Iran. Arch Iran Med. 2013; 16 (6): 324-9.

6. Campos F, Carrasquilla G, Koriyama C, et al. Risk factors of gastric cancer specific for tumor location and histology in Cali, Colombia. World J Gastroenterol. 2006; 12 (36): 5772-9. DOI: 10.3748/wjg.v12.i36.5772.

7. Ferguson LR. Meat and cancer. Meat Sci. 2010; 84 (2): 308-13. DOI: 10.1016/j.meatsci.2009.06.032

8. Carr PR, Walter V, Brenner H, Hoffmeister M. Meat subtypes and their association with colorectal cancer: Systematic review and meta-analysis. Int J Cancer. 2016; 138 (2): 293-302. DOI: 10.1002/ijc.29423.

9. Fang X, Wei J, He X, et al. Landscape of dietary factors associated with risk of gastric cancer: A systematic review and dose-response meta-analysis of prospective cohort studies. Eur J Cancer. 2015; 51 (18): 2820-32. DOI: 10.1016/j.ejca.2015.09.010.

10. Hu J, La Vecchia C, de Groh M, et al. Dietary cholesterol intake and cancer. Ann Oncol. 2012; 23 (2): 491-500. DOI: 10.1093/ annonc/mdr155.

11. D'Elia L, Rossi G, Ippolito R, Cappuccio FP, Strazzullo P. Habitual salt intake and risk of gastric cancer: a meta-analysis of prospective studies. Clin Nutr. 2012; 31 (4): 489-98. DOI: 10.1016/j.clnu.2012.01.003.

12. Peleteiro B, Lopes C, Figueiredo C, Lunet N. Salt intake and gastric cancer risk according to Helicobacter pylori infection, smoking, tumour site and histological type. Br J Cancer. 2011; 104 (1): 198-207. DOI: 10.1038/sj.bjc.6605993.

13. Parkin DM. 7. Cancers attributable to dietary factors in the UK in 2010. IV. Salt. Br J Cancer. 2011; 105 Suppl 2 (Suppl 2): S31S33. DOI: 10.1038/bjc.2011.480.

14. Ren JS, Kamangar F, Forman D, Islami F. Pickled food and risk of gastric cancer--a systematic review and meta-analysis of English

and Chinese literature. Cancer Epidemiol Biomarkers Prev. 2012; 21 (6): 905-15. DOl: 10.1158/1055-9965.EPI-12-0202.

15. Cai L, Zheng ZL, Zhang ZF. Risk factors for the gastric cardia cancer: a case-control study in Fujian Province. World J Gastroenterol. 2003; 9 (2): 214-8. DOI: 10.3748/wjg.v9.i2.214.

16. Joossens JV, Hill MJ, Elliott $P$, et al. Dietary salt, nitrate and stomach cancer mortality in 24 countries. European Cancer Prevention (ECP) and the INTERSALT Cooperative Research Group. Int J Epidemiol. 1996; 25 (3): 494-504. DOI: 10.1093/ ije/25.3.494.

17. Suwanrungruang K, Sriamporn S, Wiangnon S, et al. Lifestylerelated risk factors for stomach cancer in northeast Thailand. Asian Pac J Cancer Prev. 2008; 9 (1): 71-75.

18. Colomer R, Menéndez JA. Mediterranean diet, olive oil and cancer. Clin Transl Oncol. 2006; 8 (1): 15-21. DOI: 10.1007/ s12094-006-0090-0.

19. Laake I, Carlsen MH, Pedersen Jl, et al. Intake of trans fatty acids from partially hydrogenated vegetable and fish oils and ruminant fat in relation to cancer risk. Int J Cancer. 2013; 132 (6): 13891403. DOI: 10.1002/ijc.27737.

20. Xie Y, Huang S, He T, Su Y. Coffee consumption and risk of gastric cancer: an updated meta-analysis. Asia Pac J Clin Nutr. 2016; 25 (3): 578-88. DOI: 10.6133/apjcn.092015.07.

21. Shen Z, Liu H, Cao H. Coffee consumption and risk of gastric cancer: an updated meta-analysis. Clin Res Hepatol Gastroenterol. 2015; 39 (2): 245-53. DOI: 10.1016/j.clinre.2014.09.005.

22. Gao Y, Hu N, Han XY, et al. Risk factors for esophageal and gastric cancers in Shanxi Province, China: a case-control study. Cancer Epidemiol. 2011; 35 (6): e91-e99. DOI: 10.1016/j. canep.2011.06.006.

23. Nemati A, Mahdavi R, Naghizadeh Baghi A. Case-control study of dietary pattern and other risk factors for gastric cancer. Health Promot Perspect. 2012; 2 (1): 20-27. DOI: 10.5681/ hpp.2012.003.

24. Sieri S, Agnoli C, Pala V, et al. Dietary glycemic index, glycemic load, and cancer risk: results from the EPIC-Italy study. Sci Rep. 2017; 7 (1): 9757. DOI: 10.1038/s41598-017-09498-2.

25. Ladeiras-Lopes R, Pereira AK, Nogueira A, et al. Smoking and gastric cancer: systematic review and meta-analysis of cohort studies. Cancer Causes Control. 2008; 19 (7): 689-701. DOI: 10.1007/s10552-008-9132-y.

26. Wang PL, Xiao FT, Gong BC, Liu FN. Alcohol drinking and gastric cancer risk: a meta-analysis of observational studies. Oncotarget. 2017; 8 (58): 99013-23. DOI: 10.18632/oncotarget.20918.

27. Everatt R, Tamosiunas A, Kuzmickiene I, et al. Alcohol consumption and risk of gastric cancer: a cohort study of men in Kaunas, 
Lithuania, with up to 30 years follow-up. BMC Cancer. 2012; 12: 475. Published 2012 Oct 15. DOI: 10.1186/1471-2407-12-475.

28. Duell EJ, Travier N, Lujan-Barroso L, et al. Alcohol consumption and gastric cancer risk in the European Prospective Investigation into Cancer and Nutrition (EPIC) cohort. Am J Clin Nutr. 2011; 94 (5): 1266-75. DOI: 10.3945/ajcn.111.012351.

29. Rauf A, Imran M, Butt MS, Nadeem M, Peters DG, Mubarak MS. Resveratrolas ananti-canceragent: Areview. CritRevFood SciNutr. 2018; 58 (9): 1428-47. DOI: 10.1080/10408398.2016.1263597.

30. Malekzadeh MM, Khademi H, Pourshams A, et al. Opium use and risk of mortality from digestive diseases: a prospective cohort study. Am J Gastroenterol. 2013; 108 (11): 1757-65. DOI: 10.1038/ajg.2013.336.

31. Shakeri R, Malekzadeh R, Etemadi A, et al. Opium: an emerging risk factor for gastric adenocarcinoma. Int J Cancer. 2013; 133 (2): 455-61. DOI: 10.1002/ijc.28018.

32. Chen Y, Tan F, Wei L, et al. Sleep duration and the risk of cancer: a systematic review and meta-analysis including dose-response relationship. BMC Cancer. 2018; 18 (1): 1149. DOI: 10.1186/ s12885-018-5025-y.

33. Gu F, Xiao Q, Chu LW, et al. Sleep Duration and Cancer in the NIH-AARP Diet and Health Study Cohort. PLoS One. 2016; 11 (9): e0161561. DOI: 10.1371/journal.pone.0161561.

34. Chen Y, Tan F, Wei L, et al. Sleep duration and the risk of cancer: a systematic review and meta-analysis including dose-response relationship. BMC Cancer. 2018; 18 (1): 1149. DOI: 10.1186/ s12885-018-5025-y.

35. Herszényi L, Juhász M, Mihály E, Tulassay Z. A fekélybetegség és a stressz [Peptic ulcer disease and stress]. Orv Hetil. 2015; 156 (35): 1426-9. DOI: 10.1556/650.2015.30249.

36. Hardbower DM, de Sablet T, Chaturvedi R, Wilson KT. Chronic inflammation and oxidative stress: the smoking gun for Helicobacter pylori-induced gastric cancer? Gut Microbes. 2013; 4 (6): 475-81. DOl: 10.4161/gmic.25583.

37. Zhang X, Zhang $\mathrm{Y}, \mathrm{He} Z$, et al. Chronic stress promotes gastric cancer progression and metastasis: an essential role for ADRB2. Cell Death Dis. 2019; 10 (11): 788. DOl: 10.1038/s41419-0192030-2.

38. Xie SH, Chen R, Zhao DL, et al. Status of non-steroidal antiinflammatory drugs use in areas with a high incidence of upper gastrointestinal cancer in China: a multi-center cross-sectional survey. Zhonghua Yu Fang Yi Xue Za Zhi. 2019; 53 (11): 1098103. DOI: 10.3760/cma.j.issn.0253-9624.2019.11.005.

39. Dai $Y$, Wang $W H$. Non-steroidal anti-inflammatory drugs in prevention of gastric cancer. World J Gastroenterol. 2006; 12 (18): 2884-9. DOI: 10.3748/wjg.v12.i18.2884.

40. Farrow DC, Vaughan TL, Hansten PD, et al. Use of aspirin and other nonsteroidal anti-inflammatory drugs and risk of esophagea and gastric cancer. Cancer Epidemiol Biomarkers Prev. 1998; 7 (2): 97-102.

41. Zaleska M, Mozenska O, Bil J. Statins use and cancer: an update. Future Oncol. 2018; 14 (15): 1497-509. DOI: 10.2217/fon-20170543.

42. Wu XD, Zeng $\mathrm{K}$, Xue $F Q$, Chen $\mathrm{JH}$, Chen $\mathrm{YQ}$. Statins are associated with reduced risk of gastric cancer: a meta-analysis. Eur J Clin Pharmacol. 2013; 69 (10): 1855-60. DOI: 10.1007/ s00228-013-1547-z.

43. Wu AH, Tseng CC, Bernstein L. Hiatal hernia, reflux symptoms, body size, and risk of esophageal and gastric adenocarcinoma. Cancer. 2003; 98 (5): 940-8. DOI: 10.1002/cncr.11568.

44. Derakhshan $\mathrm{MH}$, Malekzadeh $\mathrm{R}$, Watabe $\mathrm{H}$, et al. Combination of gastric atrophy, reflux symptoms and histological subtype indicates two distinct aetiologies of gastric cardia cancer. Gut. 2008; 57 (3): 298-305. DOI: 10.1136/gut.2007.137364.

45. Hansen S, Vollset SE, Derakhshan MH, et al. Two distinct aetiologies of cardia cancer; evidence from premorbid serological markers of gastric atrophy and Helicobacter pylori status. Gut. 2007; 56 (7): 918-25. DOI: 10.1136/gut.2006.114504.

46. Li F, Du H, Li S, Liu J. The Association Between Metabolic Syndrome and Gastric Cancer in Chinese. Front Oncol. 2018; 8: 326. Published 2018 Aug 23. DOI: 10.3389/fonc.2018.00326.

47. Abudawood M. Diabetes and cancer: A comprehensive review. J Res Med Sci. 2019; 24: 94. DOI: 10.4103/jrms.JRMS 242_19.
48. Miao ZF, Xu H, Xu YY, et al. Diabetes mellitus and the risk of gastric cancer: a meta-analysis of cohort studies. Oncotarget. 2017; 8 (27): 44881-92. DOl: 10.18632/oncotarget.16487.

49. Kwon HJ, Park MI, Park SJ, et al. Insulin Resistance Is Associated with Early Gastric Cancer: A Prospective Multicenter Case Control Study. Gut Liver. 2019; 13 (2): 154-60. DOI: 10.5009/gnl17556.

50. Ikeda $\mathrm{F}, \mathrm{DOI} Y$, Yonemoto $\mathrm{K}$, et al. Hyperglycemia increases risk of gastric cancer posed by Helicobacter pylori infection: a population-based cohort study. Gastroenterology. 2009; 136 (4): 1234-41. DOI: 10.1053/j.gastro.2008.12.045.

51. Cheung KS, Chan EW, Chen L, Seto WK, Wong ICK, Leung WK. Diabetes Increases Risk of Gastric Cancer After Helicobacter pylori Eradication: A Territory-Wide Study With Propensity Score Analysis. Diabetes Care. 2019; 42 (9): 1769-75. DOI: 10.2337/ dc19-0437.

52. Huang YK, Kang WM, Ma ZQ, Liu YQ, Zhou L, Yu JC. Body mass index, serum total cholesterol, and risk of gastric highgrade dysplasia: A case-control study among Chinese adults. Medicine (Baltimore). 2016; 95 (35): e4730. DOI: 10.1097/ MD.0000000000004730.

53. Kim HY. Metabolic syndrome is associated with gastric dysplasia. Eur J Gastroenterol Hepatol. 2011; 23 (10): 871-5. DOI: 10.1097/ MEG.0b013e328349aa18.

54. Avgerinos KI, Spyrou N, Mantzoros CS, Dalamaga M. Obesity and cancer risk: Emerging biological mechanisms and perspectives. Metabolism. 2019; 92: 121-35. DOI: 10.1016/j. metabol.2018.11.001.

55. Garai J, Uddo RB, Mohler MC, et al. At the crossroad between obesity and gastric cancer. Methods Mol Biol. 2015; 1238: 689707. DOI: 10.1007/978-1-4939-1804-1_36.

56. Li Q, Zhang J, Zhou Y, Qiao L. Obesity and gastric cancer. Front Biosci (Landmark Ed). 2012; 17: 2383-90. DOI: 10.2741/4059.

57. DuX, Hidayat K, Shi BM. Abdominal obesity and gastroesophageal cancer risk: systematic review and meta-analysis of prospective studies. Biosci Rep. 2017; 37 (3): BSR20160474. Published 2017 May 11. DOI: 10.1042/BSR20160474.

58. Song M, Latorre G, Ivanovic-Zuvic D, Camargo MC, Rabkin CS. Autoimmune Diseases and Gastric Cancer Risk: A Systematic Review and Meta-Analysis. Cancer Res Treat. 2019; 51 (3): 841 50. DOI: 10.4143/crt.2019.151.

59. Suzuki H, Iwasaki E, Hibi T. Helicobacter pylori and gastric cancer. Gastric Cancer. 2009; 12 (2): 79-87. DOI: 10.1007/s10120-0090507-X.

60. Lee SA, Kang D, Shim KN, Choe JW, Hong WS, Choi H. Effect of diet and Helicobacter pylori infection to the risk of early gastric cancer. J Epidemiol. 2003; 13 (3): 162-8. DOI: 10.2188/jea.13.162.

61. Sheu MJ, Yang HB, Sheu BS, Cheng HC, Lin CY, Wu JJ. Erythrocyte Lewis (A+B-) host phenotype is a factor with familial clustering for increased risk of Helicobacter pylori-related noncardiac gastric cancer. J Gastroenterol Hepatol. 2006; 21 (6) 1054-8. DOI: 10.1111/j.1440-1746.2005.04050.x.

62. Lee YC, Chiang TH, Chou CK, et al. Association Between Helicobacter pylori Eradication and Gastric Cancer Incidence: A Systematic Review and Meta-analysis. Gastroenterology. 2016; 150 (5): 1113-24. DOI: 10.1053/j.gastro.2016.01.028.

63. Zeng ZM, Luo FF, Zou LX, et al. Human papillomavirus as potential risk factor for gastric cancer: a meta-analysis of 1,917 cases. Onco Targets Ther. 2016; 9: 7105-14. DOI: 10.2147/OTT. S115053.

64. Coghill AE, Hildesheim A. Epstein-Barr virus antibodies and the risk of associated malignancies: review of the literature. Am J Epidemiol. 2014; 180 (7): 687-95. DOI: 10.1093/aje/kwu176.

65. Koshiol J, Qiao YL, Mark SD, et al. Epstein-Barr virus serology and gastric cancer incidence and survival. Br J Cancer. 2007; 97 (11): 1567-9. DOI: 10.1038/sj.bjc.6604063.

66. Levine $\mathrm{PH}$, Stemmermann G, Lennette ET, Hildesheim A, Shibata D, Nomura A. Elevated antibody titers to Epstein-Barr virus prior to the diagnosis of Epstein-Barr-virus-associated gastric adenocarcinoma. Int J Cancer. 1995; 60 (5): 642-4. DOI: 10.1002/ijc.2910600513.

67. de Souza CRT, Almeida MCA, Khayat AS, et al. Association between Helicobacter pylori, Epstein-Barr virus, human papillomavirus and gastric adenocarcinomas. World J Gastroenterol. 2018; 24 (43): 
4928-38. DOI: 10.3748/wjg.v24.i43.4928.

68. Zou L, Luo K, Qiao O, Xu J. Global gene expression responses to lodine-125 radiation in three human gastric cancer cell lines. Zhonghua Wai Ke Za Zhi. 2014; 52 (8): 612-6.

69. Hauptmann M, Fossa SD, Stovall M, et al. Increased stomach cancer risk following radiotherapy for testicular cancer. $\mathrm{Br} J$ Cancer. 2015; 112 (1): 44-51. DOI: 10.1038/bjc.2014.552.

70. Nandakumar A, Uwatoko F, Yamamoto M, et al. Radiation-induced Epstein-Barr virus reactivation in gastric cancer cells with latent EBV infection. Tumour Biol. 2017; 39 (7): 1010428317717718. DOI: 10.1177/1010428317717718.

71. Uthman OA, Jadidi E, Moradi T. Socioeconomic position and incidence of gastric cancer: a systematic review and metaanalysis. J Epidemiol Community Health. 2013; 67 (10): 854-60. DOI: 10.1136/jech-2012-201108.

72. Mendoza D, Herrera P, Gilman RH, et al. Variation in the prevalence of gastric cancer in Perú. Int J Cancer. 2008; 123 (2): 414-20. DOI: $10.1002 / \mathrm{ijc} .23420$.

73. Rota M, Alicandro G, Pelucchi C, et al. Education and gastric cancer risk-An individual participant data meta-analysis in the StoP project consortium [published correction appears in Int $J$ Cancer. 2020 Jun 1;146(11):E6]. Int J Cancer. 2020; 146 (3): 671-81. DOI: 10.1002/ijc.32298.

74. Ji J, Hemminki K. Socio-economic and occupational risk factors for gastric cancer: a cohort study in Sweden. Eur J Cancer Prev. 2006; 15 (5): 391-7. DOI: 10.1097/00008469-200610000-00003.

75. Santibañez M, Alguacil J, de la Hera MG, et al. Occupational exposures and risk of stomach cancer by histological type. Occup Environ Med. 2012; 69 (4): 268-75. DOI: 10.1136/ oemed-2011-100071

76. Welling R, Beaumont JJ, Petersen SJ, Alexeeff GV, Steinmaus C. Chromium VI and stomach cancer: a meta-analysis of the current epidemiological evidence. Occup Environ Med. 2015; 72 (2): 151-9. DOl: 10.1136/oemed-2014-102178

77. Choi YJ, Kim N. Gastric cancer and family history. Korean J Intern Med. 2016; 31 (6): 1042-53. DOI: 10.3904/kjim.2016.147.

78. Oliveira C, Pinheiro H, Figueiredo J, Seruca R, Carneiro F. Familial gastric cancer: genetic susceptibility, pathology, and implications for management. Lancet Oncol. 2015; 16 (2): e60-e70. DOI: 10.1016/S1470-2045(14)71016-2.

79. Yaghoobi M, Bijarchi R, Narod SA. Family history and the risk of gastric cancer. Br J Cancer. 2010; 102 (2): 237-42. DOI: 10.1038/ sj.bjc. 6605380 .

80. La Vecchia C, Negri E, Franceschi S, Gentile A. Family history and the risk of stomach and colorectal cancer. Cancer. 1992; 70 (1): 50-55. DOl: 10.1002/1097-0142(19920701)70.

81. Kokkola A, Sipponen P. Gastric carcinoma in young adults. Hepatogastroenterology. 2001; 48 (42): 1552-1555.

82. Shin $\mathrm{CM}$, Kim N, Yang HJ, et al. Stomach cancer risk in gastric cancer relatives: interaction between Helicobacter pylori infection and family history of gastric cancer for the risk of stomach cancer. J Clin Gastroenterol. 2010; 44 (2): e34-e39. DOI: 10.1097/ MCG.0b013e3181a159c4.

83. Brenner H, Arndt V, Stürmer T, Stegmaier C, Ziegler H, Dhom G. Individual and joint contribution of family history and Helicobacter pylori infection to the risk of gastric carcinoma. Cancer. 2000; 88 (2): 274-9

84. Hansford S, Kaurah P, Li-Chang H, et al. Hereditary Diffuse Gastric Cancer Syndrome: CDH1 Mutations and Beyond. JAMA Oncol. 2015; 1 (1): 23-32. DOI: 10.1001/jamaoncol.2014.168

85. Pharoah PD, Guilford P, Caldas C; International Gastric Cancer Linkage Consortium. Incidence of gastric cancer and breast cancer in $\mathrm{CDH} 1$ (E-cadherin) mutation carriers from hereditary diffuse gastric cancer families. Gastroenterology. 2001; 121 (6): 1348-53. DOI: 10.1053/gast.2001.29611.

86. Petrovchich I, Ford JM. Genetic predisposition to gastric cancer. Semin Oncol. 2016; 43 (5): 554-9. DOI: 10.1053/j. seminoncol.2016.08.006.

87. Hearle N, Schumacher V, Menko FH, et al. Frequency and spectrum of cancers in the Peutz-Jeghers syndrome. Clin Cancer Res. 2006; 12 (10): 3209-15. DOI: 10.1158/1078-0432.CCR-060083

88. Giardiello FM, Brensinger JD, Tersmette AC, et al. Very high risk of cancer in familial Peutz-Jeghers syndrome. Gastroenterology. 2000; 119 (6): 1447-53. DOI: 10.1053/gast.2000.20228.

89. Gupta S, Provenzale D, Llor X, et al. NCCN Guidelines Insights: Genetic/Familial High-Risk Assessment: Colorectal, Version 2.2019. J Natl Compr Canc Netw. 2019; 17 (9): 1032-41. DOI: 10.6004/jnccn.2019.0044.

90. Jakubowska A, Nej K, Huzarski T, Scott RJ, Lubiński J. BRCA2 gene mutations in families with aggregations of breast and stomach cancers. Br J Cancer. 2002; 87 (8): 888-91. DOI: 10.1038/sj.bjc.6600562.

91. Moiseyenko VM, Volkov NM, Suspistin EN, et al. Evidence for predictive role of BRCA1 and bTUBIII in gastric cancer. Med Oncol. 2013; 30 (2): 545. DOI: 10.1007/s12032-013-0545-4.

92. Mayor $\mathrm{PC}$, Eng $\mathrm{KH}$, Singel $\mathrm{KL}$, et al. Cancer in primary immunodeficiency diseases: Cancer incidence in the United States Immune Deficiency Network Registry. J Allergy Clin Immunol. 2018; 141 (3): 1028-035. DOI: 10.1016/j.jaci.2017.05.024.

93. Resnick ES, Moshier EL, Godbold JH, Cunningham-Rundles C. Morbidity and mortality in common variable immune deficiency over 4 decades. Blood. 2012; 119 (7): 1650-7. DOI: 10.1182/ blood-2011-09-377945.

94. Lichtenstein P, Holm NV, Verkasalo PK, et al. Environmental and heritable factors in the causation of cancer-analyses of cohorts of twins from Sweden, Denmark, and Finland. N Engl J Med. 2000; 343 (2): 78-85. DOI: 10.1056/NEJM200007133430201

95. Tian J, Liu G, Zuo C, Liu C, He W, Chen H. Genetic polymorphisms and gastric cancer risk: a comprehensive review synopsis from meta-analysis and genome-wide association studies. Cancer Biol Med. 2019; 16 (2): 361-89. DOI: 10.20892/j.issn.20953941.2018 .0290

96. Setiawan VW, Yu GP, Lu QY, et al. Allium vegetables and stomach cancer risk in China. Asian Pac J Cancer Prev. 2005; 6 (3): 387-95.

97. Zhou Y, Zhuang W, Hu W, Liu GJ, Wu TX, Wu XT. Consumption of large amounts of Allium vegetables reduces risk for gastric cancer in a meta-analysis. Gastroenterology. 2011; 141 (1): 80-89. DOI: 10.1053/j.gastro.2011.03.057

98. Fleischauer AT, Poole C, Arab L. Garlic consumption and cancer prevention: meta-analyses of colorectal and stomach cancers. Am J Clin Nutr. 2000; 72 (4): 1047-52. DOI: 10.1093/ajcn/72.4.1047.

99. Zhang Z, Xu G, Ma M, Yang J, Liu X. Dietary fiber intake reduces risk for gastric cancer: a meta-analysis. Gastroenterology. 2013; 145 (1): 113-20. DOI: 10.1053/j.gastro.2013.04.001.

100. Hou IC, Amarnani S, Chong MT, Bishayee A. Green tea and the risk of gastric cancer: epidemiological evidence. World $J$ Gastroenterol. 2013; 19 (24): 3713-22. DOI: 10.3748/wjg.v19. i24.3713.

101. Zhou Y, Wang T, Meng Q, Zhai S. Association of carotenoids with risk of gastric cancer: A meta-analysis. Clin Nutr. 2016; 35 (1): 109-16. DOI: 10.1016/j.clnu.2015.02.003.

102. Kong P, Cai Q, Geng Q, et al. Vitamin intake reduce the risk of gastric cancer: meta-analysis and systematic review of randomized and observational studies. PLoS One. 2014; 9 (12): e116060. DOI: 10.1371/journal.pone.0116060.

103. Ma JL, Zhang L, Brown LM, et al. Fifteen-year effects of Helicobacter pylori, garlic, and vitamin treatments on gastric cancer incidence and mortality. J Natl Cancer Inst. 2012; 104 (6): 488-92. DOI: 10.1093/jnci/djs003.

104. Mahendra A, Karishma, Choudhury BK, et al. Vitamin D and gastrointestinal cancer. J Lab Physicians. 2018; 10 (1): 1-5. DOI: 10.4103/JLP.JLP_49_17.

105. Vyas N, Companioni RC, Tiba M, et al. Association between serum vitamin $D$ levels and gastric cancer: A retrospective chart analysis. World J Gastrointest Oncol. 2016; 8 (9): 688-94. DOI: 10.4251/wjgo.v8.i9.688

106. Singh K, Gandhi S, Batool R. A Case-Control Study of the Association between Vitamin D Levels and Gastric Incomplete Intestinal Metaplasia. Nutrients. 2018; 10 (5): 629. DOI: 10.3390/ nu10050629.

107. Kurtzke JF, Hyllested K. Validity of the epidemics of multiple sclerosis in the Faroe Islands. Neuroepidemiology. 1988; 7 (4): 190-227. DOI: 10.1159/000110154.

108. Gonda TA, Kim YI, Salas MC, et al. Folic acid increases global DNA methylation and reduces inflammation to prevent Helicobacter- 
associated gastric cancer in mice. Gastroenterology. 2012; 142 (4): 824-33.e7. DOI: 10.1053/j.gastro.2011.12.058.

109. Brenner DR, Yannitsos DH, Farris MS, Johansson M, Friedenreich CM. Leisure-time physical activity and lung cancer risk: A systematic review and meta-analysis. Lung Cancer. 2016; 95: 17-27. DOI: 10.1016/j.lungcan.2016.01.021.

110. de Boer MC, Wörner EA, Verlaan D, van Leeuwen PAM. The Mechanisms and Effects of Physical Activity on Breast Cancer. Clin Breast Cancer. 2017; 17 (4): 272-8. DOI: 10.1016/j. clbc.2017.01.006

111. Singh S, Edakkanambeth Varayil J, Devanna S, Murad MH, lyer

\section{Литература}

1. Ang TL, Fock KM. Clinical epidemiology of gastric cancer. Singapore Med J. 2014; 55 (12): 621-8. DOI: 10.11622/smedj.2014174.

2. Marqués-Lespier JM, González-Pons M, Cruz-Correa M. Current Perspectives on Gastric Cancer. Gastroenterol Clin North Am. 2016; 45 (3): 413-28. DOI: 10.1016/.gtc.2016.04.002.

3. Isobe Y, Nashimoto A, Akazawa K, et al. Gastric cancer treatment in Japan: 2008 annual report of the JGCA nationwide registry. Gastric Cancer. 2011; 14 (4): 301-16. DOI: 10.1007/s10120011-0085-6.

4. Cai $L$, Zheng ZL, Zhang ZF. Risk factors for the gastric cardia cancer: a case-control study in Fujian Province. World $J$ Gastroenterol. 2003; 9 (2): 214-8. DOI: 10.3748/wjg.v9.i2.214.

5. Zamani N, Hajifaraji M, Fazel-tabar Malekshah A, Keshtkar AA, Esmaillzadeh A, Malekzadeh R. A case-control study of the relationship between gastric cancer and meat consumption in Iran. Arch Iran Med. 2013; 16 (6): 324-9.

6. Campos F, Carrasquilla G, Koriyama C, et al. Risk factors of gastric cancer specific for tumor location and histology in Cali, Colombia. World J Gastroenterol. 2006; 12 (36): 5772-9. DOI: 10.3748/wjg.v12.i36.5772.

7. Ferguson LR. Meat and cancer. Meat Sci. 2010; 84 (2): 308-13. DOI: 10.1016/j.meatsci.2009.06.032

8. Carr PR, Walter V, Brenner H, Hoffmeister M. Meat subtypes and their association with colorectal cancer: Systematic review and meta-analysis. Int J Cancer. 2016; 138 (2): 293-302. DOI: 10.1002/ijc.29423.

9. Fang X, Wei J, He X, et al. Landscape of dietary factors associated with risk of gastric cancer: A systematic review and dose-response meta-analysis of prospective cohort studies. Eur J Cancer. 2015; 51 (18): 2820-32. DOI: 10.1016/j.ejca.2015.09.010.

10. Hu J, La Vecchia C, de Groh M, et al. Dietary cholesterol intake and cancer. Ann Oncol. 2012; 23 (2): 491-500. DOI: 10.1093/ annonc/mdr155.

11. D'Elia L, Rossi G, Ippolito R, Cappuccio FP, Strazzullo P. Habitual salt intake and risk of gastric cancer: a meta-analysis of prospective studies. Clin Nutr. 2012; 31 (4): 489-98. DOI: 10.1016/j.clnu.2012.01.003.

12. Peleteiro B, Lopes C, Figueiredo C, Lunet N. Salt intake and gastric cancer risk according to Helicobacter pylori infection, smoking, tumour site and histological type. Br J Cancer. 2011; 104 (1): 198-207. DOI: 10.1038/sj.bjc.6605993.

13. Parkin DM. 7. Cancers attributable to dietary factors in the UK in 2010. IV. Salt. Br J Cancer. 2011; 105 Suppl 2 (Suppl 2): S31S33. DOI: 10.1038/bjc.2011.480.

14. Ren JS, Kamangar F, Forman D, Islami F. Pickled food and risk of gastric cancer--a systematic review and meta-analysis of English and Chinese literature. Cancer Epidemiol Biomarkers Prev. 2012; 21 (6): 905-15. DOI: 10.1158/1055-9965.EPI-12-0202.

15. Cai L, Zheng ZL, Zhang ZF. Risk factors for the gastric cardia cancer: a case-control study in Fujian Province. World $J$ Gastroenterol. 2003; 9 (2): 214-8. DOl: 10.3748/wjg.v9.i2.214.

16. Joossens JV, Hill MJ, Elliott P, et al. Dietary salt, nitrate and stomach cancer mortality in 24 countries. European Cancer Prevention (ECP) and the INTERSALT Cooperative Research Group. Int J Epidemiol. 1996; 25 (3): 494-504. DOI: 10.1093/ ije/25.3.494.

17. Suwanrungruang K, Sriamporn S, Wiangnon S, et al. Lifestylerelated risk factors for stomach cancer in northeast Thailand.
PG. Physical activity is associated with reduced risk of gastric cancer: a systematic review and meta-analysis. Cancer Prev Res (Phila). 2014; 7 (1): 12-22. DOI: 10.1158/1940-6207.CAPR13-0282.

112. Bae SE, Jung HY, Kang J, et al. Effect of Helicobacter pylon eradication on metachronous recurrence after endoscopic resection of gastric neoplasm. Am J Gastroenterol. 2014; 109 (1): 60-67. DOI: 10.1038/ajg.2013.404.

113. Hamid RN, Akkurt ZM. Hereditary Tumor Syndromes with Skin Involvement. Dermatol Clin. 2019; 37 (4): 607-13. DOI: 10.1016/j. det.2019.05.016

Asian Pac J Cancer Prev. 2008: 9 (1):71-75

18. Colomer R, Menéndez JA. Mediterranean diet, olive oil and cancer. Clin Transl Oncol. 2006; 8 (1): 15-21. DOI: 10.1007/ s12094-006-0090-0.

19. Laake I, Carlsen MH, Pedersen JI, et al. Intake of trans fatty acids from partially hydrogenated vegetable and fish oils and ruminant fat in relation to cancer risk. Int J Cancer. 2013; 132 (6): 13891403. DOI: $10.1002 / \mathrm{ijc} .27737$.

20. Xie Y, Huang S, He T, Su Y. Coffee consumption and risk of gastric cancer: an updated meta-analysis. Asia Pac J Clin Nutr. 2016; 25 (3): 578-88. DOI: 10.6133/apjcn.092015.07.

21. Shen Z, Liu H, Cao H. Coffee consumption and risk of gastric cancer: an updated meta-analysis. Clin Res Hepatol Gastroenterol. 2015; 39 (2): 245-53. DOI: 10.1016/j.clinre.2014.09.005.

22. Gao $Y$, Hu N, Han $X Y$, et al. Risk factors for esophageal and gastric cancers in Shanxi Province, China: a case-control study. Cancer Epidemiol. 2011; 35 (6): e91-e99. DOI: 10.1016/j. canep.2011.06.006

23. Nemati A, Mahdavi R, Naghizadeh Baghi A. Case-control study of dietary pattern and other risk factors for gastric cancer. Health Promot Perspect. 2012; 2 (1): 20-27. DOI: 10.5681/ hpp.2012.003.

24. Sieri S, Agnoli C, Pala V, et al. Dietary glycemic index, glycemic load, and cancer risk: results from the EPIC-Italy study. Sci Rep. 2017; 7 (1): 9757. DOI: 10.1038/s41598-017-09498-2.

25. Ladeiras-Lopes R, Pereira AK, Nogueira A, et al. Smoking and gastric cancer: systematic review and meta-analysis of cohort studies. Cancer Causes Control. 2008; 19 (7): 689-701. DOI: 10.1007/s10552-008-9132-y.

26. Wang PL, Xiao FT, Gong BC, Liu FN. Alcohol drinking and gastric cancer risk: a meta-analysis of observational studies. Oncotarget. 2017: 8 (58): 99013-23. DOI: 10.18632/oncotarget.20918.

27. Everatt R, Tamosiunas A, Kuzmickiene I, et al. Alcohol consumption and risk of gastric cancer: a cohort study of men in Kaunas, Lithuania, with up to 30 years follow-up. BMC Cancer. 2012; 12 475. Published 2012 Oct 15. DOI: 10.1186/1471-2407-12-475.

28. Duell EJ, Travier N, Lujan-Barroso L, et al. Alcohol consumption and gastric cancer risk in the European Prospective Investigation into Cancer and Nutrition (EPIC) cohort. Am J Clin Nutr. 2011; 94 (5): 1266-75. DOI: 10.3945/ajcn.111.012351.

29. Rauf A, Imran M, Butt MS, Nadeem M, Peters DG, Mubarak MS Resveratrol as an anti-canceragent: Areview. CritRevFood SciNutr. 2018; 58 (9): 1428-47. DOI: 10.1080/10408398.2016.1263597.

30. Malekzadeh MM, Khademi H, Pourshams A, et al. Opium use and risk of mortality from digestive diseases: a prospective cohort study. Am J Gastroenterol. 2013; 108 (11): 1757-65. DOI: 10.1038/ajg.2013.336.

31. Shakeri R, Malekzadeh R, Etemadi A, et al. Opium: an emerging risk factor for gastric adenocarcinoma. Int J Cancer. 2013; 133 (2): 455-61. DOI: 10.1002/ijc.28018.

32. Chen $Y$, Tan $F$, Wei L, et al. Sleep duration and the risk of cancer: a systematic review and meta-analysis including dose-response relationship. BMC Cancer. 2018; 18 (1): 1149. DOI: 10.1186/ s12885-018-5025-y.

33. Gu F, Xiao Q, Chu LW, et al. Sleep Duration and Cancer in the $\mathrm{NIH}$-AARP Diet and Health Study Cohort. PLoS One. 2016; 11 (9): e0161561. DOI: 10.1371/journal.pone.0161561.

34. Chen Y, Tan F, Wei L, et al. Sleep duration and the risk of cancer: 
a systematic review and meta-analysis including dose-response relationship. BMC Cancer. 2018; 18 (1): 1149. DOI: 10.1186/ s12885-018-5025-y

35. Herszényi L, Juhász M, Mihály E, Tulassay Z. A fekélybetegség és a stressz [Peptic ulcer disease and stress]. Orv Hetil. 2015; 156 (35): 1426-9. DOI: 10.1556/650.2015.30249.

36. Hardbower DM, de Sablet T, Chaturvedi R, Wilson KT. Chronic inflammation and oxidative stress: the smoking gun for Helicobacter pylori-induced gastric cancer? Gut Microbes. 2013; 4 (6): 475-81. DOI: 10.4161/gmic.25583.

37. Zhang $\mathrm{X}$, Zhang $\mathrm{Y}, \mathrm{He} Z$, et al. Chronic stress promotes gastric cancer progression and metastasis: an essential role for ADRB2. Cell Death Dis. 2019; 10 (11): 788. DOI: 10.1038/s41419-0192030-2.

38. Xie SH, Chen R, Zhao DL, et al. Status of non-steroidal antiinflammatory drugs use in areas with a high incidence of upper gastrointestinal cancer in China: a multi-center cross-sectional survey. Zhonghua Yu Fang Yi Xue Za Zhi. 2019; 53 (11): 1098103. DOI: $10.3760 / \mathrm{cma}$.j.issn.0253-9624.2019.11.005.

39. Dai $Y$, Wang WH. Non-steroidal anti-inflammatory drugs in prevention of gastric cancer. World J Gastroenterol. 2006; 12 (18): 2884-9. DOI: 10.3748/wjg.v12.i18.2884.

40. Farrow DC, Vaughan TL, Hansten PD, et al. Use of aspirin and other nonsteroidal anti-inflammatory drugs and risk of esophageal and gastric cancer. Cancer Epidemiol Biomarkers Prev. 1998; 7 (2): 97-102.

41. Zaleska M, Mozenska O, Bil J. Statins use and cancer: an update. Future Oncol. 2018; 14 (15): 1497-509. DOI: 10.2217/fon-20170543.

42. Wu XD, Zeng K, Xue FQ, Chen JH, Chen YQ. Statins are associated with reduced risk of gastric cancer: a meta-analysis. Eur J Clin Pharmacol. 2013; 69 (10): 1855-60. DOI: 10.1007/ s00228-013-1547-z.

43. Wu AH, Tseng CC, Bernstein L. Hiatal hernia, reflux symptoms, body size, and risk of esophageal and gastric adenocarcinoma. Cancer. 2003; 98 (5): 940-8. DOI: 10.1002/cncr.11568.

44. Derakhshan $\mathrm{MH}$, Malekzadeh $\mathrm{R}$, Watabe $\mathrm{H}$, et al. Combination of gastric atrophy, reflux symptoms and histological subtype indicates two distinct aetiologies of gastric cardia cancer. Gut. 2008; 57 (3): 298-305. DOI: 10.1136/gut.2007.137364

45. Hansen S, Vollset SE, Derakhshan $\mathrm{MH}$, et al. Two distinct aetiologies of cardia cancer; evidence from premorbid serological markers of gastric atrophy and Helicobacter pylori status. Gut. 2007; 56 (7): 918-25. DOI: 10.1136/gut.2006.114504.

46. Li F, Du H, Li S, Liu J. The Association Between Metabolic Syndrome and Gastric Cancer in Chinese. Front Oncol. 2018; 8: 326. Published 2018 Aug 23. DOI: 10.3389/fonc.2018.00326.

47. Abudawood M. Diabetes and cancer: A comprehensive review. J Res Med Sci. 2019; 24: 94. DOI: 10.4103/jrms.JRMS_242_19.

48. Miao ZF, Xu H, Xu YY, et al. Diabetes mellitus and the risk of gastric cancer: a meta-analysis of cohort studies. Oncotarget. 2017; 8 (27): 44881-92. DOI: 10.18632/oncotarget.16487.

49. Kwon HJ, Park MI, Park SJ, et al. Insulin Resistance Is Associated with Early Gastric Cancer: A Prospective Multicenter Case Control Study. Gut Liver. 2019; 13 (2): 154-60. DOI: 10.5009/gnl17556.

50. Ikeda F, DOI Y, Yonemoto K, et al. Hyperglycemia increases risk of gastric cancer posed by Helicobacter pylori infection: a population-based cohort study. Gastroenterology. 2009; 136 (4): 1234-41. DOI: 10.1053/j.gastro.2008.12.045

51. Cheung KS, Chan EW, Chen L, Seto WK, Wong ICK, Leung WK. Diabetes Increases Risk of Gastric Cancer After Helicobacter pylori Eradication: A Territory-Wide Study With Propensity Score Analysis. Diabetes Care. 2019; 42 (9): 1769-75. DOl: 10.2337/ dc19-0437.

52. Huang YK, Kang WM, Ma ZQ, Liu YQ, Zhou L, Yu JC. Body mass index, serum total cholesterol, and risk of gastric highgrade dysplasia: A case-control study among Chinese adults. Medicine (Baltimore). 2016; 95 (35): e4730. DOl: 10.1097/ MD.0000000000004730.

53. Kim HY. Metabolic syndrome is associated with gastric dysplasia Eur J Gastroenterol Hepatol. 2011; 23 (10): 871-5. DOI: 10.1097/ MEG.0b013e328349aa18.

54. Avgerinos KI, Spyrou N, Mantzoros CS, Dalamaga M. Obesity and cancer risk: Emerging biological mechanisms and perspectives. Metabolism. 2019; 92: 121-35. DOI: 10.1016/j. metabol.2018.11.001.

55. Garai J, Uddo RB, Mohler MC, et al. At the crossroad between obesity and gastric cancer. Methods Mol Biol. 2015; 1238: 689707. DOI: 10.1007/978-1-4939-1804-1_36.

56. Li Q, Zhang J, Zhou Y, Qiao L. Obesity and gastric cancer. Front Biosci (Landmark Ed). 2012; 17: 2383-90. DOI: 10.2741/4059.

57. Du X, Hidayat K, Shi BM. Abdominal obesity and gastroesophageal cancer risk: systematic review and meta-analysis of prospective studies. Biosci Rep. 2017; 37 (3): BSR20160474. Published 2017 May 11. DOI: 10.1042/BSR20160474

58. Song M, Latorre G, Ivanovic-Zuvic D, Camargo MC, Rabkin CS. Autoimmune Diseases and Gastric Cancer Risk: A Systematic Review and Meta-Analysis. Cancer Res Treat. 2019; 51 (3): $841-$ 50. DOI: $10.4143 /$ crt.2019.151

59. Suzuki H, Iwasaki E, Hibi T. Helicobacter pylori and gastric cancer. Gastric Cancer. 2009; 12 (2): 79-87. DOI: 10.1007/s10120-0090507-x.

60. Lee SA, Kang D, Shim KN, Choe JW, Hong WS, Choi H. Effect of diet and Helicobacter pylori infection to the risk of early gastric cancer. J Epidemiol. 2003; 13 (3): 162-8. DOI: 10.2188/jea.13.162.

61. Sheu MJ, Yang HB, Sheu BS, Cheng HC, Lin CY, Wu JJ. Erythrocyte Lewis (A+B-) host phenotype is a factor with familial clustering for increased risk of Helicobacter pylori-related noncardiac gastric cancer. J Gastroenterol Hepatol. 2006; 21 (6) 1054-8. DOI: 10.1111/j.1440-1746.2005.04050.x

62. Lee YC, Chiang TH, Chou CK, et al. Association Between Helicobacter pylori Eradication and Gastric Cancer Incidence: A Systematic Review and Meta-analysis. Gastroenterology. 2016; 150 (5): 1113-24. DOI: 10.1053/j.gastro.2016.01.028.

63. Zeng ZM, Luo FF, Zou LX, et al. Human papillomavirus as a potential risk factor for gastric cancer: a meta-analysis of 1,917 cases. Onco Targets Ther. 2016; 9: 7105-14. DOI: 10.2147/OTT. S115053.

64. Coghill AE, Hildesheim A. Epstein-Barr virus antibodies and the risk of associated malignancies: review of the literature. Am J Epidemiol. 2014; 180 (7): 687-95. DOI: 10.1093/aje/kwu176.

65. Koshiol J, Qiao YL, Mark SD, et al. Epstein-Barr virus serology and gastric cancer incidence and survival. Br J Cancer. 2007; 97 (11): 1567-9. DOI: 10.1038/sj.bjc.6604063.

66. Levine PH, Stemmermann G, Lennette ET, Hildesheim A, Shibata D, Nomura A. Elevated antibody titers to Epstein-Barr virus prior to the diagnosis of Epstein-Barr-virus-associated gastric adenocarcinoma. Int J Cancer. 1995; 60 (5): 642-4. DOI: 10.1002/ijc.2910600513.

67. de Souza CRT, Almeida MCA, Khayat AS, et al. Association between Helicobacter pylori, Epstein-Barr virus, human papillomavirus and gastric adenocarcinomas. World J Gastroenterol. 2018; 24 (43): 4928-38. DOI: 10.3748/wjg.v24.i43.4928.

68. Zou L, Luo K, Qiao O, Xu J. Global gene expression responses to lodine-125 radiation in three human gastric cancer cell lines. Zhonghua Wai Ke Za Zhi. 2014; 52 (8): 612-6.

69. Hauptmann M, Fossa SD, Stovall M, et al. Increased stomach cancer risk following radiotherapy for testicular cancer. $\mathrm{Br} J$ Cancer. 2015; 112 (1): 44-51. DOI: 10.1038/bjc.2014.552.

70. Nandakumar A, Uwatoko F, Yamamoto M, et al. Radiation-induced Epstein-Barr virus reactivation in gastric cancer cells with latent EBV infection. Tumour Biol. 2017; 39 (7): 1010428317717718. DOI: $10.1177 / 1010428317717718$

71. Uthman OA, Jadidi E, Moradi T. Socioeconomic position and incidence of gastric cancer: a systematic review and metaanalysis. J Epidemiol Community Health. 2013; 67 (10): 854-60. DOI: 10.1136/jech-2012-201108.

72. Mendoza D, Herrera P, Gilman RH, et al. Variation in the prevalence of gastric cancer in Perú. Int J Cancer. 2008; 123 (2): 414-20. DOI: 10.1002/ijc.23420.

73. Rota M, Alicandro G, Pelucchi $\mathrm{C}$, et al. Education and gastric cancer risk-An individual participant data meta-analysis in the StoP project consortium [published correction appears in Int $J$ Cancer. 2020 Jun 1;146(11):E6]. Int J Cancer. 2020; 146 (3): 671-81. DOI: 10.1002/ijc.32298.

74. Ji J, Hemminki K. Socio-economic and occupational risk factors 
for gastric cancer: a cohort study in Sweden. Eur J Cancer Prev. 2006; 15 (5): 391-7. DOI: 10.1097/00008469-200610000-00003.

75. Santibañez M, Alguacil J, de la Hera MG, et al. Occupational exposures and risk of stomach cancer by histological type. Occup Environ Med. 2012; 69 (4): 268-75. DOI: 10.1136/ oemed-2011-100071

76. Welling R, Beaumont JJ, Petersen SJ, Alexeeff GV, Steinmaus C. Chromium VI and stomach cancer: a meta-analysis of the current epidemiological evidence. Occup Environ Med. 2015; 72 (2): 151-9. DOI: 10.1136/oemed-2014-102178.

77. Choi YJ, Kim N. Gastric cancer and family history. Korean J Intern Med. 2016; 31 (6): 1042-53. DOI: 10.3904/kjim.2016.147.

78. Oliveira C, Pinheiro H, Figueiredo J, Seruca R, Carneiro F. Familial gastric cancer: genetic susceptibility, pathology, and implications for management. Lancet Oncol. 2015; 16 (2): e60-e70. DOI: 10.1016/S1470-2045(14)71016-2.

79. Yaghoobi M, Bijarchi R, Narod SA. Family history and the risk of gastric cancer. Br J Cancer. 2010; 102 (2): 237-42. DOI: 10.1038/ sj.bjc. 6605380.

80. La Vecchia C, Negri E, Franceschi S, Gentile A. Family history and the risk of stomach and colorectal cancer. Cancer. 1992; 70 (1): 50-55. DOI: 10.1002/1097-0142(19920701)70.

81. Kokkola A, Sipponen P. Gastric carcinoma in young adults. Hepatogastroenterology. 2001; 48 (42): 1552-1555.

82. Shin CM, Kim N, Yang HJ, et al. Stomach cancer risk in gastric cancer relatives: interaction between Helicobacter pylori infection and family history of gastric cancer for the risk of stomach cancer. J Clin Gastroenterol. 2010; 44 (2): e34-e39. DOI: 10.1097/ MCG.0b013e3181a159c4.

83. Brenner H, Arndt V, Stürmer T, Stegmaier C, Ziegler H, Dhom G. Individual and joint contribution of family history and Helicobacter pylori infection to the risk of gastric carcinoma. Cancer. 2000; 88 (2): 274-9.

84. Hansford S, Kaurah P, Li-Chang H, et al. Hereditary Diffuse Gastric Cancer Syndrome: CDH1 Mutations and Beyond. JAMA Oncol. 2015; 1 (1): 23-32. DOI: 10.1001/jamaoncol.2014.168

85. Pharoah PD, Guilford P, Caldas C; International Gastric Cancer Linkage Consortium. Incidence of gastric cancer and breast cancer in $\mathrm{CDH1}$ (E-cadherin) mutation carriers from hereditary diffuse gastric cancer families. Gastroenterology. 2001; 121 (6): 1348-53. DOI: 10.1053/gast.2001.29611.

86. Petrovchich I, Ford JM. Genetic predisposition to gastric cancer. Semin Oncol. 2016; 43 (5): 554-9. DOI: 10.1053/j. seminoncol.2016.08.006.

87. Hearle N, Schumacher V, Menko FH, et al. Frequency and spectrum of cancers in the Peutz-Jeghers syndrome. Clin Cancer Res. 2006; 12 (10): 3209-15. DOI: 10.1158/1078-0432.CCR-060083.

88. Giardiello FM, Brensinger JD, Tersmette AC, et al. Very high risk of cancer in familial Peutz-Jeghers syndrome. Gastroenterology. 2000; 119 (6): 1447-53. DOI: 10.1053/gast.2000.20228.

89. Gupta S, Provenzale D, Llor X, et al. NCCN Guidelines Insights: Genetic/Familial High-Risk Assessment: Colorectal, Version 2.2019. J Natl Compr Canc Netw. 2019; 17 (9): 1032-41. DOI: 10.6004/jnccn.2019.0044.

90. Jakubowska A, Nej K, Huzarski T, Scott RJ, Lubiński J. BRCA2 gene mutations in families with aggregations of breast and stomach cancers. Br J Cancer. 2002; 87 (8): 888-91. DOI: 10.1038/sj.bjc.6600562.

91. Moiseyenko VM, Volkov NM, Suspistin EN, et al. Evidence for predictive role of BRCA1 and bTUBIII in gastric cancer. Med Oncol. 2013; 30 (2): 545. DOI: 10.1007/s12032-013-0545-4.

92. Mayor $\mathrm{PC}$, Eng $\mathrm{KH}$, Singel $\mathrm{KL}$, et al. Cancer in primary immunodeficiency diseases: Cancer incidence in the United States Immune Deficiency Network Registry. J Allergy Clin Immunol. 2018; 141 (3): 1028-035. DOI: 10.1016/j.jaci.2017.05.024.

93. Resnick ES, Moshier EL, Godbold JH, Cunningham-Rundles C. Morbidity and mortality in common variable immune deficiency over 4 decades. Blood. 2012; 119 (7): 1650-7. DOI: 10.1182/ blood-2011-09-377945

94. Lichtenstein P, Holm NV, Verkasalo PK, et al. Environmental and heritable factors in the causation of cancer-analyses of cohorts of twins from Sweden, Denmark, and Finland. N Engl J Med. 2000 343 (2): 78-85. DOI: 10.1056/NEJM200007133430201

95. Tian J, Liu G, Zuo C, Liu C, He W, Chen H. Genetic polymorphisms and gastric cancer risk: a comprehensive review synopsis from meta-analysis and genome-wide association studies. Cancer Biol Med. 2019; 16 (2): 361-89. DOI: 10.20892/j.issn.20953941.2018 .0290

96. Setiawan VW, Yu GP, Lu QY, et al. Allium vegetables and stomach cancer risk in China. Asian Pac J Cancer Prev. 2005; 6 (3): 387-95.

97. Zhou Y, Zhuang W, Hu W, Liu GJ, Wu TX, Wu XT. Consumption of large amounts of Allium vegetables reduces risk for gastric cancer in a meta-analysis. Gastroenterology. 2011; 141 (1): 80-89. DOI: 10.1053/j.gastro.2011.03.057

98. Fleischauer AT, Poole C, Arab L. Garlic consumption and cancer prevention: meta-analyses of colorectal and stomach cancers. Am J Clin Nutr. 2000; 72 (4): 1047-52. DOI: 10.1093/ajcn/72.4.1047.

99. Zhang Z, Xu G, Ma M, Yang J, Liu X. Dietary fiber intake reduces risk for gastric cancer: a meta-analysis. Gastroenterology. 2013; 145 (1): 113-20. DOI: 10.1053/.gastro.2013.04.001.

100. Hou IC, Amarnani S, Chong MT, Bishayee A. Green tea and the risk of gastric cancer: epidemiological evidence. World $J$ Gastroenterol. 2013; 19 (24): 3713-22. DOI: 10.3748/wjg.v19. i24.3713.

101. Zhou Y, Wang T, Meng Q, Zhai S. Association of carotenoids with risk of gastric cancer: A meta-analysis. Clin Nutr. 2016; 35 (1): 109-16. DOI: 10.1016/j.clnu.2015.02.003.

102. Kong $P$, Cai $Q$, Geng Q, et al. Vitamin intake reduce the risk of gastric cancer: meta-analysis and systematic review of randomized and observational studies. PLoS One. 2014; 9 (12): e116060. DOI: 10.1371/journal.pone.0116060

103. Ma JL, Zhang L, Brown LM, et al. Fifteen-year effects of Helicobacter pylori, garlic, and vitamin treatments on gastric cancer incidence and mortality. J Natl Cancer Inst. 2012; 104 (6): 488-92. DOI: 10.1093/jnci/djs003.

104. Mahendra A, Karishma, Choudhury BK, et al. Vitamin D and gastrointestinal cancer. J Lab Physicians. 2018; 10 (1): 1-5. DOI: 10.4103/JLP.JLP 49 17.

105. Vyas N, Companioni RC, Tiba M, et al. Association between serum vitamin D levels and gastric cancer: A retrospective chart analysis. World J Gastrointest Oncol. 2016; 8 (9): 688-94. DOl: 10.4251/wjgo.v8.i9.688

106. Singh K, Gandhi S, Batool R. A Case-Control Study of the Association between Vitamin D Levels and Gastric Incomplete Intestinal Metaplasia. Nutrients. 2018; 10 (5): 629. DOI: 10.3390/ nu10050629.

107. Kurtzke JF, Hyllested K. Validity of the epidemics of multiple sclerosis in the Faroe Islands. Neuroepidemiology. 1988; 7 (4): 190-227. DOI: 10.1159/000110154.

108. Gonda TA, Kim YI, Salas MC, et al. Folic acid increases global DNA methylation and reduces inflammation to prevent Helicobacterassociated gastric cancer in mice. Gastroenterology. 2012; 142 (4): 824-33.e7. DOI: 10.1053/j.gastro.2011.12.058.

109. Brenner DR, Yannitsos DH, Farris MS, Johansson M, Friedenreich CM. Leisure-time physical activity and lung cancer risk: A systematic review and meta-analysis. Lung Cancer. 2016; 95: 17-27. DOI: 10.1016/i.lungcan.2016.01.021.

110. de Boer MC, Wörner EA, Verlaan D, van Leeuwen PAM. The Mechanisms and Effects of Physical Activity on Breast Cancer. Clin Breast Cancer. 2017; 17 (4): 272-8. DOI: 10.1016/j. clbc.2017.01.006

111. Singh S, Edakkanambeth Varayil J, Devanna S, Murad MH, lyer PG. Physical activity is associated with reduced risk of gastric cancer: a systematic review and meta-analysis. Cancer Prev Res (Phila). 2014; 7 (1): 12-22. DOI: 10.1158/1940-6207.CAPR13-0282.

112. Bae SE, Jung HY, Kang J, et al. Effect of Helicobacter pylori eradication on metachronous recurrence after endoscopic resection of gastric neoplasm. Am J Gastroenterol. 2014; 109 (1): 60-67. DOI: 10.1038/ajg.2013.404.

113. Hamid RN, Akkurt ZM. Hereditary Tumor Syndromes with Skin Involvement. Dermatol Clin. 2019; 37 (4): 607-13. DOI: 10.1016/j. det.2019.05.016 